\title{
Is Fostamatinib a possible drug for COVID-19? - A computational study
}

\author{
Sovan Saha ${ }^{1,+}$, Anup Kumar Halder ${ }^{2,+}$, Soumyendu Sekhar Bandyopadhyay ${ }^{2}$, Piyali \\ Chatterjee $^{3}$, Mita Nasipuri ${ }^{2}$, Debdas Bose ${ }^{4}$ and Subhadip Basu ${ }^{2, *}$ \\ ${ }^{1}$ Dr. Sudhir Chandra Sur Degree Engineering College, Computer Science and Engineering, Kolkata, 700074, \\ India \\ ${ }^{2}$ Jadavpur University, Computer Science and Engineering, Kolkata, 700032, India \\ ${ }^{3}$ Netaji Subhash Engineering College, Computer Science and Engineering, Kolkata, 700152, India \\ ${ }^{4}$ Institute of Hematology and Transfusion Medicine, Medical College Hospital, Kolkata, 700073, India \\ *subhadip.basu@jadavpuruniversity.in \\ ${ }^{+}$Equal Contribution, both shared $1^{s t}$ authorship
}

\begin{abstract}
COVID-19 has turned out to be a global pandemic within a very short period since its first origin in China in December 2019. With the gradual increase in the mortality rate all over the world, there is an urgent need for an effectual drug. Though no clinically approved vaccine or drug is available until now but scientists are trying hard to identify potential antivirals to this new coronavirus. Several drugs like hydroxychloroquine, remdesivir, azithromycin etc. are put under evaluation in more than 300 clinical trials for the treatment of COVID-19. Few of them already show encouraging results. The main agent of disease progression of COVID-19 is SARS-CoV2/nCoV, which is believed to have $\sim 89 \%$ genetic resemblance with SARS$\mathrm{CoV}$, a coronavirus responsible for the massive outbreak in 2003. With this hypothesis, a recently developed in silico Human-nCoV network and potential COVID-19 spreader proteins, have been derived from the Human-SARS-CoV protein interactions using SIS model and fuzzy thresholding, followed by a potential FDA drugs target based validation. We then perform a two-way analysis to identify the potential drug targets of COVID-19. In the first analysis, we identify the complete list of FDA drugs for the 37 level 1 and 4948 level 2 spreader proteins in this network followed by the application of a consensus strategy. In the second analysis, the same consensus strategy is applied but on a curated overlapping set of key genes identified from COVID-19 symptoms, risk factors and clinical outcome. The applied consensus strategy in both the analysis reveals that Fostamatinib, a FDA approved drug, has the highest drug consensus score both in level 1 and level 2. Further analysis reveals that Fostamatinib also targets CYP3A4, a level 2 spreader protein and the most common target for most of the potential COVID-19 drugs. A subsequent docking study also reveals that Fostamatinib has also the highest docking score with respect to 6LU7, the crystal structure of COVID-19 main protease in complex with an inhibitor N3, in comparison to other potential drugs like hydroxychloroquine, remdesivir, favipiravir and darunavir. Our computational study suggests that Fostamatinib may also be considered as one of the potential candidates for further clinical trials in pursuit to counter the spread of COVID-19.
\end{abstract}

\section{Introduction}

The world has witnessed several severe epidemics like Spanish flu, ebola, cholera etc. Now we are in the front of the most life threatening viral outburst with COVID-19. The feature which makes this new coronavirus, $\mathrm{nCoV}$, unique is its quick ability to transmit through respiratory droplets on coming in direct contact or neighborhood of any infected COVID patient ${ }^{1}$. It is considered to be one of the genera of Betacoronavirus which comes under the family of Coronaviridae. It is created by the assimilation of accessory, non-structural and structural proteins ${ }^{2}$. According to the World Health Organization (WHO) coronavirus disease dashboard ${ }^{3}$, 3,679,499 confirmed cases of COVID-19, including 254,199 deaths have been reported as of 6:32pm CEST, 7 May 2020. Many treatments of antiviral drugs are considered and implemented to terminate COVID-19 based on the prior knowledge of major outbreaks of ebola, cholera etc. Moreover, along with these trial and error methods, an organized assessment of the drug chloroquine on $\mathrm{nCoV}$ has emerged ${ }^{4}$. But application of chloroquine on COVID-19 is contentious till date since these information have not been generated directly from the registered clinical trials in progress as reported by Zhang et $a l^{5}$.

Recently, a literature survey ${ }^{6}$ is implemented by a refined search in various online repositories to enfold various drug related COVID-19 research articles during the onset of this pandemic i.e. starting from January 1 and ending in March 25, 2020. Databases like Google Scholar, Science Direct, and PubMed etc. are marked as search strings for keywords like vaccine, anti-malaria drugs, treatment for COVID-19, traditional Chinese 
Medicine for COVID-19, anti-viral drugs. Almost 22 articles $^{6}$ have been filtered out based on the screening criteria as set by the computational search mechanism. In order to acquire a comparative idea about the recommended or suggested drugs till date for COVID-19, all the significant researches including these 22 articles have been extensively studied, the details of which have been listed in Table 1.

Table 1 List of significant research articles involving potential recommended drugs for COVID-19

\begin{tabular}{|c|c|c|c|c|c|}
\hline $\begin{array}{l}\text { SL. } \\
\text { No. }\end{array}$ & Journal/Article name & Involved drugs & Report type & $\begin{array}{c}\text { Drug } \\
\text { Categorization }\end{array}$ & Results/Outcome \\
\hline \multirow{4}{*}{1} & \multirow{4}{*}{$\begin{array}{l}\text { The Use of Anti- } \\
\text { Inflammatory Drugs in the } \\
\text { Treatment of People With } \\
\text { Severe Coronavirus } \\
\text { Disease } 2019 \text { (COVID-19): } \\
\text { The Perspectives of } \\
\text { Clinical Immunologists } \\
\text { From China }\end{array}$} & Glucocorticoids & \multirow{4}{*}{ Clinical } & \multirow{2}{*}{ Anti-malarial } & \multirow{4}{*}{$\begin{array}{l}\text { Confirmation of the short- } \\
\text { term efficacy of HCQ in } \\
\text { the treatment of } \\
\text { COVID-19 }\end{array}$} \\
\hline & & IL-6 antagonist & & & \\
\hline & & JAK inhibitors & & & \\
\hline & & $\begin{array}{l}\text { Chloroquine } \\
\text { (CQ)/ } \\
\text { Hydroxychloroq } \\
\text { uine (HCQ) }\end{array}$ & & $\begin{array}{l}\text { Anti- } \\
\text { inflammatory }\end{array}$ & \\
\hline \multirow[b]{2}{*}{2} & \multirow{2}{*}{$\begin{array}{l}\text { Hydroxychloroquine and } \\
\text { azithromycin as a } \\
\text { treatment of COVID-19: } \\
\text { results of an open-label } \\
\text { non-randomized clinical } \\
\text { trial }^{8}\end{array}$} & HCQ & \multirow[b]{2}{*}{ Clinical } & Anti-viral & \multirow{2}{*}{$\begin{array}{l}\text { Combination of the two is } \\
\text { effective in the } \\
\text { extermination of } \\
\text { coronavirus. }\end{array}$} \\
\hline & & Azithromycin & & $\begin{array}{l}\text { Anti- } \\
\text { inflammatory }\end{array}$ & \\
\hline 3 & $\begin{array}{lr}\text { Lianhuaqingwen } & \text { exerts } \\
\text { anti-viral and anti- } & \text { al } \\
\text { inflammatory activity } \\
\text { against novel coronavirus } \\
(\text { SARS-CoV-2) }\end{array}$ & $\begin{array}{l}\text { Lianhuaqingwen } \\
\text { (LH) }\end{array}$ & $\begin{array}{l}\text { Laboratory } \\
\text { test }\end{array}$ & $\begin{array}{c}\text { Traditional } \\
\text { Chinese Medicine }\end{array}$ & $\begin{array}{l}\text { LH hinders the replication } \\
\text { of SARS-COV-2 }\end{array}$ \\
\hline \multirow[b]{2}{*}{4} & \multirow{2}{*}{$\begin{array}{l}\text { Hydroxychloroquine, a less } \\
\text { toxic derivative of } \\
\text { chloroquine, is effective in } \\
\text { inhibiting SARS-CoV-2 } \\
\text { infection in vitro. }{ }^{10}\end{array}$} & \multirow[b]{2}{*}{ HCQ } & \multirow{2}{*}{$\begin{array}{l}\text { In vitro } \\
\text { Cytotoxicity } \\
\text { and antiviral }\end{array}$} & Anti-malarial & \multirow{2}{*}{$\begin{array}{c}\text { HCQ can effectively stop } \\
\text { the infection of SARS- } \\
\text { CoV-2 in vitro. }\end{array}$} \\
\hline & & & & $\begin{array}{l}\text { Anti- } \\
\text { inflammatory }\end{array}$ & \\
\hline \multirow{3}{*}{5} & \multirow{3}{*}{$\begin{array}{l}\text { Aminoquinolines Against } \\
\text { Coronavirus Disease } 2019 \\
\text { (COVID-19): Chloroquine } \\
\text { or Hydroxychloroquine }^{11}\end{array}$} & HCQ & \multirow{3}{*}{$\begin{array}{l}\text { Opinion } \\
\text { paper }\end{array}$} & Anti-malarial & \multirow{3}{*}{$\begin{array}{c}\text { Though both HCQ and CQ } \\
\text { are beneficial but HCQ is } \\
\text { more safer in comparison } \\
\text { to CQ }\end{array}$} \\
\hline & & $\mathrm{CQ}$ & & & \\
\hline & & $\begin{array}{l}\text { Other medicinal } \\
\text { agents }\end{array}$ & & Anti-viral & \\
\hline 6 & $\begin{array}{l}\text { Experimental Treatment } \\
\text { with Favipiravir for } \\
\text { COVID-19: An Open- } \\
\text { Label Control Study }{ }^{12}\end{array}$ & $\begin{array}{l}\text { Favipiravir } \\
\text { (FPV) }\end{array}$ & Clinical & Anti-viral & $\begin{array}{l}\text { FPV performs a faster } \\
\text { clearance of viral infection } \\
\text { with a better change in } \\
\text { chest imaging. }\end{array}$ \\
\hline \multirow[b]{2}{*}{7} & \multirow{2}{*}{$\begin{array}{l}\text { TH17 responses in } \\
\text { cytokine storm of COVID- } \\
\text { 19: An emerging target of } \\
\text { JAK2 inhibitor Fedratinib }{ }^{13}\end{array}$} & $\begin{array}{c}\text { Janus kinase } 2 \\
\text { (JAK2) }\end{array}$ & \multirow{2}{*}{$\begin{array}{l}\text { In vitro } \\
\text { study }\end{array}$} & \multirow{2}{*}{$\begin{array}{l}\text { Anti- } \\
\text { inflammatory }\end{array}$} & \multirow{2}{*}{$\begin{array}{l}\text { JAK2 inhibitor Fedratinib } \\
\text { can prevent the } \\
\text { deteriorating outcomes of } \\
\text { TH17 associated cytkine } \\
\text { storm in COVID-19. }\end{array}$} \\
\hline & & Fedratinib & & & \\
\hline \multirow[b]{2}{*}{8} & \multirow{2}{*}{$\begin{array}{l}\text { In Vitro Antiviral Activity } \\
\text { and Projection of } \\
\text { Optimized Dosing Design } \\
\text { of Hydroxychloroquine for } \\
\text { the Treatment of Severe } \\
\text { Acute Respiratory } \\
\text { Syndrome Coronavirus } 2 \\
(\text { SARS-CoV-2) } \\
\text { (14 }\end{array}$} & HCQ & \multirow[b]{2}{*}{$\begin{array}{l}\text { In vitro } \\
\text { study }\end{array}$} & \multirow[b]{2}{*}{ Anti-malarial } & \multirow[b]{2}{*}{ Inhibits COVID- 19.} \\
\hline & & CQ & & & \\
\hline \multirow[b]{2}{*}{9} & \multirow{2}{*}{$\begin{array}{l}\text { Coronavirus Disease } 2019 \\
\text { (COVID-19) Pneumonia in } \\
{\text { a Hemodialysis Patient }{ }^{15}}\end{array}$} & Lopinavir & \multirow{2}{*}{$\begin{array}{l}\text { Case study } \\
\text { on } \\
\text { Hemodialys } \\
\text { is Patient }\end{array}$} & \multirow[b]{2}{*}{ Anti-viral } & \multirow{2}{*}{$\begin{array}{l}\text { Recovery symptoms noted } \\
\text { though combination of the } \\
\text { drugs needs more testing. }\end{array}$} \\
\hline & & Ritonavir & & & \\
\hline \multirow{2}{*}{10} & \multirow{2}{*}{$\begin{array}{l}\text { Repurposing of clinically } \\
\text { approved drugs for } \\
\text { treatment of coronavirus } \\
\text { disease } 2019 \text { in a 2019- }\end{array}$} & Cepharanthine & $\begin{array}{l}\text { Cell culture } \\
\text { and }\end{array}$ & $\begin{array}{c}\text { Anti- } \\
\text { inflammatory }\end{array}$ & Reduction of cytopathic \\
\hline & & Selamectin & $\begin{array}{c}\text { pangolin } \\
\text { coronavirus }\end{array}$ & antineoplastic & effects in cell culture. \\
\hline
\end{tabular}




\begin{tabular}{|c|c|c|c|c|c|}
\hline & $\begin{array}{l}\text { novel coronavirus (2019- } \\
\text { nCoV) related coronavirus } \\
\text { model. }{ }^{16}\end{array}$ & Mefloquine & modelling & anti-parasitic & \\
\hline 11 & $\begin{array}{l}\text { Traditional } \\
\text { Medicine for COVIDese } \\
\text { Treatment }^{17}\end{array}$ & $\begin{array}{l}\text { Qingfei paidu } \\
\text { decoction }\end{array}$ & Case study & $\begin{array}{c}\text { Traditional } \\
\text { Chinese Medicine }\end{array}$ & Control COVID-19. \\
\hline \multirow[b]{2}{*}{12} & \multirow{2}{*}{$\begin{array}{l}\text { COVID-19: combining } \\
\text { antiviral and anti- } \\
\text { inflammatory treatments }{ }^{18}\end{array}$} & Baricitinib & \multirow[b]{2}{*}{ In silico } & \multirow{2}{*}{$\begin{array}{c}\text { Anti- } \\
\text { inflammatory }\end{array}$} & \multirow{2}{*}{$\begin{array}{l}\text { Favourable in COVID-19 } \\
\text { treatment. }\end{array}$} \\
\hline & & $\begin{array}{l}\text { Fedratinib } \\
\text { Ruxolitinib }\end{array}$ & & & \\
\hline 13 & $\begin{array}{l}\text { The antiviral compound } \\
\text { remdesivir potently inhibits } \\
\text { RNA-dependent RNA } \\
\text { polymerase from Middle } \\
\text { East respiratory syndrome } \\
\text { coronavirus. }{ }^{19}\end{array}$ & Remdesivir & $\begin{array}{l}\text { In vitro } \\
\text { study }\end{array}$ & Anti-viral & $\begin{array}{l}\text { High effectiveness of } \\
\text { remdesivir against RNA } \\
\text { viruses in cell-based } \\
\text { assays. }\end{array}$ \\
\hline 14 & $\begin{array}{l}\text { Virus against virus: a } \\
\text { potential treatment for } \\
\text { 2019-nCov (SARS-CoV-2) } \\
\text { and other RNA viruses. }\end{array}$ & $\begin{array}{l}\text { CRISPR/Cas } 13 \mathrm{~d} \\
\text { strategy }\end{array}$ & In vitro test & $\begin{array}{l}\text { Others } \\
\text { treatment/drugs }\end{array}$ & $\begin{array}{c}\text { Capable of RNA virus } \\
\text { treatment }\end{array}$ \\
\hline \multirow{4}{*}{15} & \multirow{4}{*}{$\begin{array}{l}\text { Therapeutic options for the } \\
2019 \text { novel coronavirus } \\
(2019-\mathrm{nCoV})^{2}\end{array}$} & Remdesivir & \multirow{4}{*}{ Opinion } & \multirow{4}{*}{ Anti-viral } & \multirow{4}{*}{$\begin{array}{l}\text { Biocontainment capability } \\
\text { against covid-19. }\end{array}$} \\
\hline & & Umifenovir & & & \\
\hline & & Oseltamivir & & & \\
\hline & & $\frac{\text { ASC09F }}{\text { Other inhibitors }}$ & & & \\
\hline 16 & $\begin{array}{l}\text { Inhibitors of RAS Might } \\
\text { Be a Good Choice for the } \\
\text { Therapy of COVID-19 } \\
\text { Pneumonia }^{21}\end{array}$ & $\begin{array}{l}\text { Renin- } \\
\text { Angiotensin } \\
\text { System (RAS) } \\
\text { inhibitors }\end{array}$ & Opinion & $\begin{array}{l}\text { Others } \\
\text { treatment/drugs }\end{array}$ & $\begin{array}{l}\text { ACEI and AT1R inhibitors } \\
\text { could be used in patients } \\
\text { with COVID-19 } \\
\text { pneumonia to reduce the } \\
\text { pulmonary inflammatory } \\
\text { response and mortality. }\end{array}$ \\
\hline \multirow[b]{2}{*}{17} & \multirow{2}{*}{$\begin{array}{l}\text { Case of the Index Patient } \\
\text { Who Caused Tertiary } \\
\text { Transmission of } \\
\text { Coronavirus Disease } 2019 \\
\text { in Korea: the Application } \\
\text { of Lopinavir/Ritonavir for } \\
\text { the Treatment of COVID- } \\
19 \text { Pneumonia Monitored } \\
\text { by Quantitative RT-PCR. }{ }^{22}\end{array}$} & Lopinavir & \multirow[b]{2}{*}{ Clinical } & \multirow[b]{2}{*}{ Anti-viral } & \multirow[b]{2}{*}{$\begin{array}{l}\text { Combat COVID-19 } \\
\text { harmful effect. }\end{array}$} \\
\hline & & RitonavirA & & & \\
\hline 18 & $\begin{array}{l}\text { Therapeutic strategies in an } \\
\text { outbreak scenario to treat } \\
\text { the novel coronavirus } \\
\text { originating in Wuhan, } \\
\text { China }{ }^{23}\end{array}$ & $\begin{array}{l}\text { Angiotensin- } \\
\text { converting } \\
\text { enzyme } 2\end{array}$ & Opinion & $\begin{array}{l}\text { Others } \\
\text { treatment/drugs }\end{array}$ & $\begin{array}{l}\text { Potentiality of ACE2-Fc to } \\
\text { act as the neutralizing } \\
\text { antibody which can be } \\
\text { used for COVID-19 } \\
\text { treatment. }\end{array}$ \\
\hline \multirow{6}{*}{19} & \multirow{6}{*}{$\begin{array}{l}\text { Remdesivir and } \\
\text { chloroquine effectively } \\
\text { inhibit the recently } \\
\text { emerged novel coronavirus } \\
(2019-n C o V) \text { in vitro. }{ }^{24}\end{array}$} & Remdesivir & \multirow{6}{*}{$\begin{array}{l}\text { In vitro } \\
\text { study }\end{array}$} & Anti-viral & \multirow{6}{*}{$\begin{array}{l}\text { Drugs proved to be } \\
\text { effective with Remdesivir } \\
\text { and chloroquine. }\end{array}$} \\
\hline & & Ribavirin & & \multirow{5}{*}{ Anti-malarial } & \\
\hline & & Penciclovir & & & \\
\hline & & $\frac{\text { Nitazoxanide }}{\text { Nafamostat }}$ & & & \\
\hline & & $\begin{array}{l}\text { Remdesivir } \\
\text { Favipiravir }\end{array}$ & & & \\
\hline & & $\begin{array}{l}\text { Favipiravir } \\
\text { Chloroquine }\end{array}$ & & & \\
\hline \multirow{3}{*}{20} & \multirow{3}{*}{$\begin{array}{lr}\text { Clinical } & \text { characteristics } \\
\text { and therapeutic procedure } \\
\text { for four cases } \\
\text { novel } & \text { with } 2019 \\
\text { pneumonia } & \text { receiving } \\
\text { combined } & \text { Chinese and } \\
\text { Western } & \text { medicine } \\
\text { treatment. }^{25} & \\
\end{array}$} & $\begin{array}{c}\text { Lopinavir/ } \\
\text { Ritonavir }\end{array}$ & \multirow{3}{*}{$\begin{array}{l}\text { Case } \\
\text { study }\end{array}$} & \multirow{2}{*}{ Anti-viral } & \multirow{3}{*}{$\begin{array}{l}\text { Effective treatment was } \\
\text { observed. }\end{array}$} \\
\hline & & Arbidol & & & \\
\hline & & Shufeng Jiedu & & Anti-malarial & \\
\hline 21 & $\begin{array}{l}\text { First case of } 2019 \text { novel } \\
\text { coronavirus in the United } \\
\text { States. }^{26}\end{array}$ & Remdesivir & $\begin{array}{l}\text { Case } \\
\text { Study on } \\
\text { single } \\
\text { patient }\end{array}$ & Anti-viral & Patient got recovered. \\
\hline 22 & $\begin{array}{l}\text { One highly suspected case } \\
\text { of novel coronavirus }\end{array}$ & $\begin{array}{c}\text { Traditional } \\
\text { Chinese }\end{array}$ & $\begin{array}{c}\text { Case } \\
\text { Study on }\end{array}$ & $\begin{array}{c}\text { Traditional } \\
\text { Chinese Medicine }\end{array}$ & Patient got recovered. \\
\hline
\end{tabular}




\begin{tabular}{|c|c|c|c|c|c|}
\hline & $\begin{array}{l}\text { pneumonia treated by } \\
\text { Integrated } \text { Traditional } \\
\text { Chinese and Western } \\
\text { medicine and nucleic acid } \\
\text { analysis. }{ }^{27} \\
\end{array}$ & Medicine & $\begin{array}{l}\text { single } \\
\text { patient }\end{array}$ & & \\
\hline 23 & $\begin{array}{l}\text { COVID-19 in patients with } \\
\text { HIV: clinical case series }{ }^{28}\end{array}$ & Darunavir & $\begin{array}{l}\text { Case } \\
\text { Study on } \\
\text { single } \\
\text { patient }\end{array}$ & Anti-viral & $\begin{array}{c}\text { Darunavir was proved to } \\
\text { be ineffective against } \\
\text { COVID-19 due to low } \\
\text { affinity. }\end{array}$ \\
\hline 24 & $\begin{array}{l}\text { Favipiravir: } \\
\text { Pharmacokinetics and } \\
\text { Concerns About Clinical } \\
\text { Trials for 2019-nCoV } \\
\text { Infection }\end{array}$ & Favipiravir & Opinion & Anti-viral & $\begin{array}{l}\text { Recommendation for use } \\
\text { in COVID-19. Needs more } \\
\text { clinical confirmation. }\end{array}$ \\
\hline 25 & $\begin{array}{l}\text { Remdesivir for COVID-19 } \\
\text { : challenges of } \\
\text { underpowered studies }\end{array}$ & Remdevesir & $\begin{array}{l}\text { Case } \\
\text { study }\end{array}$ & Anti-viral & $\begin{array}{l}\text { Effective against } \\
\text { COVID-19. }\end{array}$ \\
\hline
\end{tabular}

It can be observed from Table 1, that the most recommended drugs are like hydroxychloroquine, azithromycin, lopinavir, ritonavir, remdesivir, and favipiravir. It also signifies that the amount of data accessible for these drugs is insufficient to recommend any one of them as a treatment for COVID-19 until and unless necessary amount of appropriate clinical trials are executed. Relative data comparison is missing in almost all human related studies about COVID-19. So it is uncertain that whether the COVID infected patient actually recovers due to the application of the suggested drug or he/she recovers due to the given clinical extensive care and isolation. However, some of the in vitro studies have shown favourable results but these are all preliminary data, which need much more evidence before putting it in clinical trials.

But due to daily increase in the number of deaths ${ }^{3}$, there is an urgent need for the identification of a potential vaccine/drug which will eventually eradicate COVID-19. So, with no other alternatives left, clinical trials has been started by $\mathrm{WHO}^{30}$ on all the suggested drugs till date including the ones as mentioned in Table 1, which are somehow proved to be substantially beneficial on case studies of COVID-19.

Drug design needs proper understanding of disease transmission mechanism which can be effectively done through the analysis of Host-pathogen protein-protein interaction networks (PPIN) ${ }^{31}$. Pathogen is detrimental in disease progression as it has the potential to transform itself by mutation. Infection of pathogen gets broadcasted through the connecting edge or interaction between host and pathogen. Thus, proper exploration of target proteins and its interactions in Host-pathogen protein-protein interaction ${ }^{32}$ networks is essential for potential drug discovery. However, there is no approved Human-nCoV PPIN till date. So, this motivates us to develop a Human-nCoV PPIN through SIS model ${ }^{33}$ and fuzzy thresholding. Further study of protein targets of potential Food and Drug Administration (FDA) drugs ${ }^{34}$ of COVID-19 in our network shows that FDA approved drug, Fostamatinib $^{35}$, can be a potential drug for COVID-19 treatment. Rigel Pharmaceuticals, Inc. got approval for TAVALISSE (fostamatinib disodium hexahydrate) for the treatment of Chronic Immune Thrombocytopenia ${ }^{36}$ from FDA on 17/04/2018. The key points which are associated with this research work can be highlighted as:

- Recently we have developed an in silico model to identify potential spreader proteins in a Human-nCoV interaction network ${ }^{37,38}$.

- The developed model was validated using the target proteins of the potential FDA drugs ${ }^{34}$ for COVID-19 treatment.

- A two-way analysis: 1) Human-nCoV interaction network analysis 2) COVID-19 symptoms, risk factors and clinical outcome based analysis have been implemented to detect the potential candidate FDA drugs for COVID-19.

- In the first analysis, spreader proteins in a Human-nCoV interaction network are analyzed using available DrugBank data ${ }^{39,40}$. Potential FDA drugs having these spreader proteins as known targets are identified. A consensus strategy has been employed to rank the drugs having the highest overlap of target proteins with respect to the level-1 and level-2 spreader nodes in the Human-nCoV interaction network.

- In the second analysis, various human genes associated with COVID-19 symptoms ${ }^{41}$, risk factors ${ }^{41}$ and clinical outcome $^{41}$ are detected using disease-gene dataset fetched from DisGeNET ${ }^{42}$. These multiple gene sets are 
compared with each other using molbiotools ${ }^{43}$. The resultant gene set is overlapped with curated dataset of COVID-19 (under category respiratory tract disease \& viral disease) released from the Comparative Toxicogenomics Database (CTD) ${ }^{44}$ to find the most common overlapping gene set associated with COVID-19. The most active top 10 key genes from this set are identified at each of level-1 and level-2 in our Human-nCoV interaction network based on the sorting of fuzzy (level-1) and spreadability index score (level-2) in descending order. These key genes/spreader proteins are analyzed using available DrugBank data ${ }^{39,40}$. Potential FDA drugs having these spreader proteins as known targets are identified. Then the same consensus strategy, as in first analysis, has been applied.

- In both the analysis, Fostamatinib ${ }^{35}$, an FDA approved drug and commonly used for the treatment of chronic immune thrombocytopenia (ITP) ${ }^{45}$, ranks as the top having most overlap of target proteins in both the level-1 and level-2 networks

- Further analysis reveals that Fostamatinib also targets CAYP34A ${ }^{46,47}$, a common target for almost all the FDA approved drugs ${ }^{34}$ for COVID- 19.

- Fostamatinib is used for thrombocytopenia ${ }^{46}$ which is also associated with severe coronavirus disease 2019 (COVID-19) infections ${ }^{48}$.

- Fostamatinib also generates the highest docking score with 6LU7 ${ }^{49}$ (the crystal structure of COVID-19 main protease in complex with an inhibitor N3) among the other potential FDA drugs ${ }^{34}$.

\section{Dataset}

Our proposed methodology involves 4 datasets: 1) Human PPIN ${ }^{50,51}$ 2) SARS-CoV PPIN ${ }^{52}$ 3) SARS-CoVHuman PPIN ${ }^{52}$ and 4) SARS-CoV2 proteins $^{53}$. The overall dataset statistics is highlighted in Table 2.

Table 2 Description and details of the datasets

\begin{tabular}{|c|c|c|c|}
\hline Database Name & Description & Nodes & Interactions/Edges \\
\hline Human PPIN & Human-human protein interactions & 21557 & 342353 \\
\hline SARS-CoV PPIN & SARS-CoV-SARS-CoV protein interactions & 7 & ---- \\
\hline SARS-CoV-Human PPIN & SARS-CoV-Human protein interactions & 120 & 118 \\
\hline SARS-CoV2 proteins & UniProt collected reviewed COVID19 proteins & 14 & ---- \\
\hline
\end{tabular}

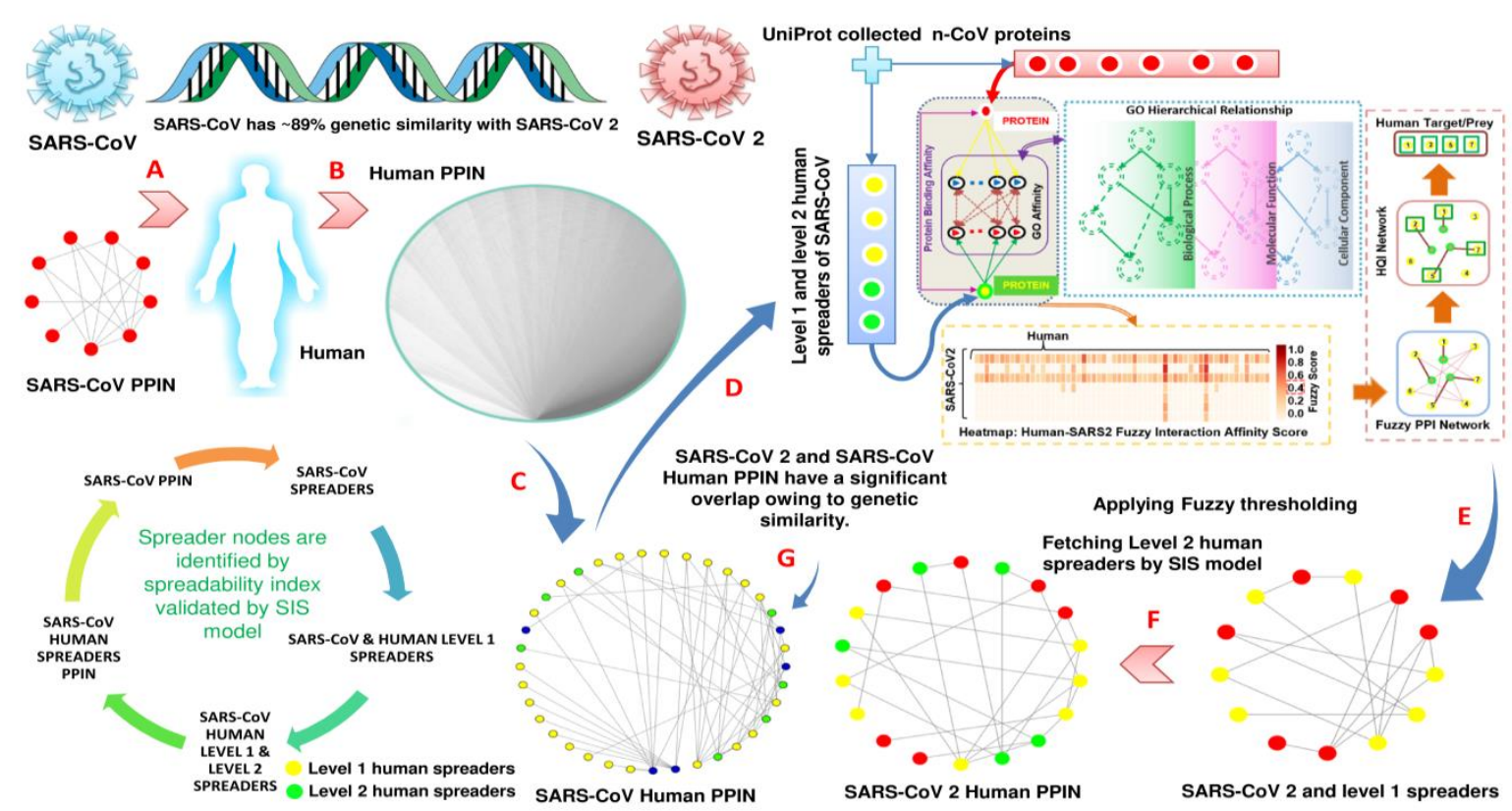

Figure 1 Formation of SARS-CoV-Human and COVID19-Human PPIN. Blue nodes represent SARS-CoV spreaders while yellow and green denotes level 1 and level 2 human spreaders respectively in SARS-CoV- 
Human PPIN. In SARS-CoV2-Human PPIN red nodes denotes SARS-CoV2 spreaders while yellow and green hold the same meaning as that of SARS-CoV-Human PPIN.

\section{Methods}

The entire working mechanism for identifying Fostamatinib as one of the potential drug for COVID19 treatment can be categorized in 4 major sections: 1) detection of spreader nodes ${ }^{37}$ in Human-nCoV PPIN 2) identification of potential FDA approved drugs with respect to COVID19 spreader nodes using Human-nCoV interaction network analysis 3) identification of potential candidate FDA drugs with respect to COVID-19 spreader nodes using COVID-19 symptoms, risk factors and clinical outcome based analysis 4) computational docking of potential drugs with respect to COVID19 protein structures.

\section{Detection of spreader nodes in Human-nCoV PPIN}

No clinically approved PPIN of Human-nCoV is available till date. So, an attempt has been made to construct a Human-nCoV PPIN based on the available PPIN information of SARS-CoV which have $\sim 89 \%$ similarity ${ }^{54,55}$ with SARS-CoV2. Not every protein in a PPIN is a spreader protein/node. Spreader proteins are considered to be those specific proteins which have unique fast capability of transmitting infection in its neighbourhood in a short period of time ${ }^{37}$. They are identified through spreadability index computed by the combination of three terminologies: 1) Edge ratio $^{56}$ 2) Neighbourhood density ${ }^{56}$ and 3) node weight ${ }^{57}$. Proteins having high spreadability index are spreader proteins. Identification of spreader proteins is conducted initially in SARS-CoV PPIN dataset. Corresponding connected human proteins i.e. level 1 and level 2 of selected SARS-CoV spreader proteins are selected from SARS-CoV-Human PPIN and Human PPIN dataset respectively. Hence, spreader proteins in level 1 and level 2 human proteins of SARS-CoV are detected by spreadability index. The selected spreader nodes are also validated by Susceptible-Infected-Susceptible (SIS) model $^{33}$ (see Figure 1). This results in the formation of a PPIN which consists of 7 SARS-CoV, 24 level 1 and 111 level 2 human spreader proteins respectively under low threshold ${ }^{37}$. The potential Human-nCoV interactions have been identified using developed in silico fuzzy PPI model ${ }^{58}$. In this model, SARS-COV spreader (level-1 and level-2) proteins in human are considered as the candidate set of interactors for $\mathrm{nCoV}^{38}$. The $\mathrm{nCoV}$-Human pair-wise relationships are quantified using the semantic similarity of their annotated GO pairs. A hybrid approach has been applied to assess the semantic similarity between any GO target pairs using the topological properties of three GO sub graphs (BP: Biological Process, MF: Molecular Function and CC: Cellular Component) ${ }^{59}$. These GO-level assessment scores are incorporated to obtain the fuzzy interaction affinity (score ranges [0, 1]) between the target Human and nCoV protein pair and results (see Figure 1). The high specificity (99.9\%) has been achieved on a threshold of 0.4 fuzzy interaction affinity score on a benchmark Human PPI dataset. Finally, with the high specificity threshold, potential interactions are identified between $\mathrm{nCoV}$ bait and human prey ${ }^{38}$.

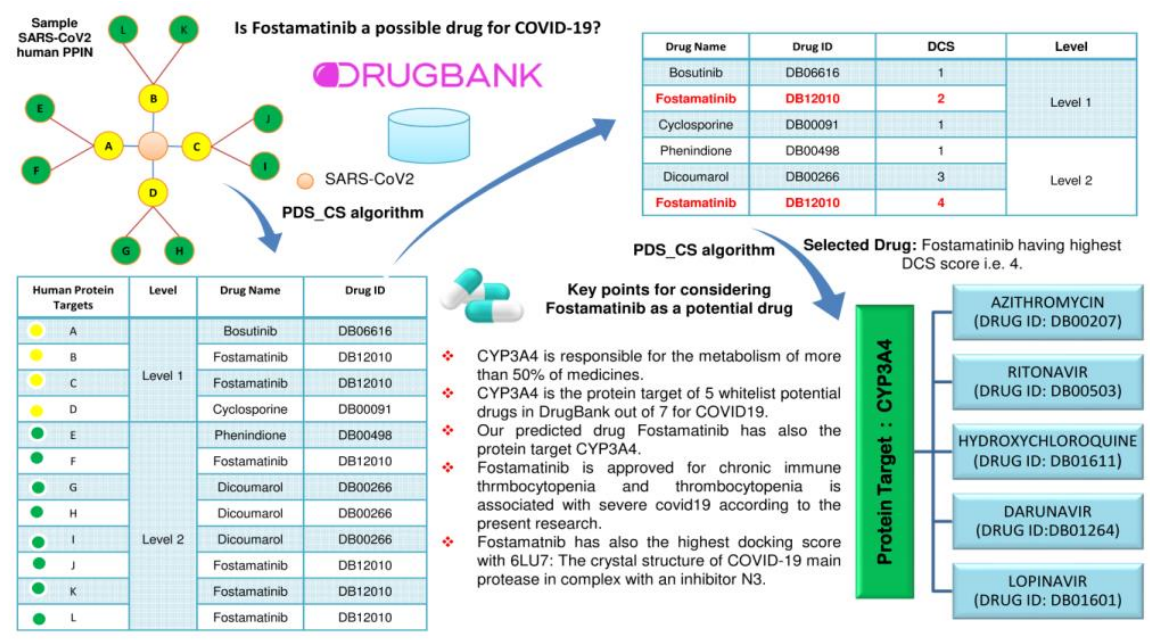

Figure 2 Consensus approach adopted to choose Fostamatinib as a potential COVID19 drug. Other connecting biological links for choosing the same have been also highlighted. 
Algorithm-1: Potential Drug Selection using Consensus Strategy (PDS_CS)

Input: The set of spreader proteins in COVID19-human PPIN, as $S^{l}=\left\{S_{1}, S_{2} \ldots \ldots S_{n}\right\}$

The set of drugs listed in DrugBank, $D^{l}=\left\{D_{1}, D_{2} \ldots . D_{n}\right\}$ for spreader protein $S^{i},(1 \leq i \leq n)$.

Output: $\boldsymbol{m x K e y -}$ a potential drug for COVID19

$D L^{1} \leftarrow[], D L^{2} \leftarrow[], \quad$ \# Empty list of drug for level-1 and level-2 spreader

$D c^{1} \leftarrow\{\}, D c^{2} \leftarrow\{\} \quad$ \# Empty dictionary for drug consensus score (DCS) for drugs

for each spreader protein $\boldsymbol{S}^{\boldsymbol{i}}$ from $\boldsymbol{S}^{\boldsymbol{l}=\mathbf{1}} \boldsymbol{d o}$

if $\boldsymbol{S}^{i} \in D_{t}\left(D_{k}\right)$ then append $D_{k}$ in $D L^{1}$

End if

End for

for each drug $\boldsymbol{D}_{\boldsymbol{i}}$ from $D L^{1}$ do

compute $D C S^{1}\left(D_{i}\right)$ and

$D c^{1}\left[D_{i}\right] \leftarrow D C S^{1}\left(D_{i}\right)$

End for

for each spreader protein $\boldsymbol{S}^{\boldsymbol{i}}$ from $\boldsymbol{S}^{\mathbf{l}=\mathbf{2}}$ do

if $\boldsymbol{S}^{\boldsymbol{i}} \in D_{t}\left(D_{k}\right)$ then

append $D_{k}$ in $D L^{2}$

End if

End for

for each drug $D_{i}$ from $\mathbf{D L}^{2}$ do

compute $D C S^{2}\left(D_{i}\right)$ and

$D c^{2}\left[D_{i}\right] \leftarrow D C S^{2}\left(D_{i}\right)$

End for

$D_{c_{\text {sort }}^{1}} \leftarrow \operatorname{sort}_{\text {desc }}\left(D c^{1}\right)$

$D c_{\text {sort }}^{2} \leftarrow \operatorname{sort}_{\text {desc }}\left(D c^{2}\right)$

if $D c_{\text {sort }}^{1}\left(D_{0}^{1}\right)>D c_{\text {sort }}^{2}\left(D_{0}^{2}\right)$ then

mxKey $\leftarrow D_{0}^{1} \quad$ \# drug $D$ from $D c^{1}$ with highest $D C S^{1}$ value in $D L^{1}$

else

mxKey $\leftarrow D_{0}^{2} \quad$ \# drug $D$ from $D c^{1}$ with highest $D C S^{2}$ value in $D L^{1}$

return mxKey

$D_{t}\left(D_{k}\right)$ : Target proteins of drug $D_{k}$

$D C S^{t}\left(D_{i}\right)$ : Drug Consensus Score of drug $D_{i}$ at level $\boldsymbol{t}$

$\operatorname{sort}_{\text {desc }}\left(D c^{f}\right)$ : Descending ordered sorting of dictionary $D c^{f}$, based on the values of the dictionary.

$f$-level of spreader protein. 


\section{Identification of potential candidate FDA drugs with respect to COVID-19 spreader nodes using Human-nCoV interaction network analysis}

Once the COVID19-human PPIN is formed, all the level 1 and level 2 human proteins of COVID19 are mapped with their corresponding drugs from DrugBank ${ }^{39}$. DrugBank is an online repository ${ }^{40}$ which contains comprehensive data about drugs, drug protein targets and information about drug metabolism. Due to the high quality annotation in DrugBank, it becomes the mostly used databases in almost all in silico methodologies which are involved in drug design, docking of drugs and drug interaction prediction. It contains near about $60 \%$ and $10 \%$ of FDA approved and experimental drugs respectively ${ }^{39}$. On proper analysis, it has been observed that various spreader nodes in COVID19-human PPIN are the protein targets of potential COVID19 FDA listed drugs $^{34}$ : hydroxychloroquine ${ }^{8,60}$, azithromycin ${ }^{8}$, lopinavir ${ }^{61}$, ritonavir $^{62}$, remdesivir ${ }^{63-65}$, and favipiravir ${ }^{66,67}$. The details of significant number of overlap between spreader nodes and drug protein targets are highlighted in Table $3^{38}$. It can be observed from Table 3, that hydroxychloroquine has the highest hit/overlap i.e. 4 while each of azithromycin, lopinavir, ritonavir and darunavir has 2 hits $^{38}$. Remdesivir and favipiravir has one hit individually ${ }^{38}$. Remdesivir is the only drug that acts directly on COVID19 protein R1AB_SARS2.

Table 3 Details of overlap of spreader nodes and potential COVID19 FDA listed drugs

\begin{tabular}{|c|c|c|c|c|}
\hline Sl. No. & COVID19 FDA listed Drugs & DrugBank ID & Drug Protein targets/ Spreader nodes & No. of hits \\
\hline 1 & Hydroxychloroquine & DB01611 & TLR9, ACE2, CYP3A4, ABCB1 & 4 \\
\hline 2 & Azithromycin & DB00207 & CYP3A4, ABCB1 & 2 \\
\hline 3 & Lopinavir & DB01601 & CYP3A4, ABCB1 & 2 \\
\hline 4 & Ritonavir & DB00503 & CYP3A4, ABCB1 & 2 \\
\hline 5 & Remdesivir & DB14761 & R1AB_SARS2 & 1 \\
\hline 6 & Favipiravir & DB12466 & ABCB1 & 1 \\
\hline 7 & Darunavir & DB01264 & CYP3A4, ABCB1 & 2 \\
\hline
\end{tabular}

Significant overlapping results of drug targets and spreader nodes in Table 3 motivates us to do further analysis and to develop a consensus strategy to identify a potential drug for COVID19 treatment. The consensus strategy is described in Algorithm 1 (PDS_CS). Drug consensus score (DCS) is used in PDS_CS which is defined as the frequency of occurrences of a drug at a particular level of PPIN. Execution of PDS_CS algorithm is also highlighted in Figure 2 by considering a sample random COVID19-Human PPIN.

\section{Identification of potential candidate FDA drugs with respect to COVID-19 spreader nodes using COVID-19 symptoms, risk factors and clinical outcome based analysis}

COVID-19 is associated with certain health symptoms like cough, fever, breathing difficulty etc. These symptoms are linked with specific human gene sets which are chosen as the possible targets (preys) by the bait i.e. $\mathrm{nCoV}$. The same is also true for other risk factors, clinical outcomes of COVID-19. So, all these genes under the mentioned categorization are grouped together ${ }^{41}$ from the disease-gene dataset which is available from DisGeNET. DisGeNET ${ }^{42}$ is considered to be one of the major resources which cover all the relevant information about various diseases. These multiple gene sets are compared with each other ${ }^{41}$ using molbiotools ${ }^{43}$. The resultant gene set is then again compared ${ }^{41}$ with curated COVID-19 dataset available in Comparative Toxicogenomics Database (CTD ${ }^{44}$ under the category of respiratory tract disease \& viral disease to obtain an overlapping gene set. $\mathrm{CTD}^{44}$ is yet another significant resource which collects, organizes and stores scientific data which describes the interrelationship between proteins, pathways, interactions, drugs etc. The overlapping gene set is further intersected with the spreader protein set in level-1 and level-2 of our generated Human-nCoV interaction network ${ }^{38}$. Top 10 key genes are selected from the resultant intersection in each of both the levels based on the fuzzy score and spreadability index score in score in level-1 and level-2 respectively. These genes are considered to be the most significant genes which play an important role in COVID-19 transmission ${ }^{68-72}$ as well as in its prevention ${ }^{73-77}$ in Human-nCoV interaction network. Potential FDA drugs having these key genes/spreader proteins as known targets are identified from DrugBank data ${ }^{39,40}$. Then PDS_CS algorithm is executed to identify the most potential candidate FDA drug for COVID19. 


\section{Computational molecular docking of potential drugs with respect to 6LU7, the crystal structure of COVID-19 main protease}

One of the most powerful approaches for structure based drug discovery is molecular docking. It is defined as the analysis of how well more than one molecular structures (drug and protein or enzyme) get attached with each other $^{78}$. In other word, docking can be interpreted as molecular modeling methodology, which is implemented to anticipate how small molecules i.e. ligands interrelate with protein i.e. enzyme. Jin $e t a l^{49}$ detected N3, which is defined as a mechanism-based inhibitor. The detection is executed by computer-aided drug design. Subsequently, they also identified the crystal structure ${ }^{49}$ of COVID-19 virus $\boldsymbol{M}^{\text {Pro }}$ in complex with this compound. It is enlisted with id: 6LU7 in Protein Data Bank (PDB) ${ }^{79}$. Protein-ligand docking is executed by using Molegro Virtual Docker (version: 6.0) between potential COVID19 FDA listed drugs and 6LU7 to measure the effectiveness of the drug on COVID19. Identification of potential binding site is done by using grid based cavity prediction. Blind docking is chosen due to the absence of active ligand in the predicted cavity. Flexible ligand models are used. Ligands are oriented differently and energy scores are the basis of ranking. For each ligand, the entire algorithm is set at 1500 iterations with a simplex evolution size of 10 runs. Compounds which require lowest energy to bind are considered to be the best. The molecules of the potential COVID19 FDA listed drugs are downloaded from DrugBank ${ }^{39}$ in Structure data file (SDF) format (3D conformer). The docking returns two types of scores: 1) Moldock scores and 2) Rerank scores. These scores assist in the identification of the best molecules docked in the selected target site. All the molecules are sorted based on these scores which represent the lowest energy required to get tied up with amino acid (AA) components.

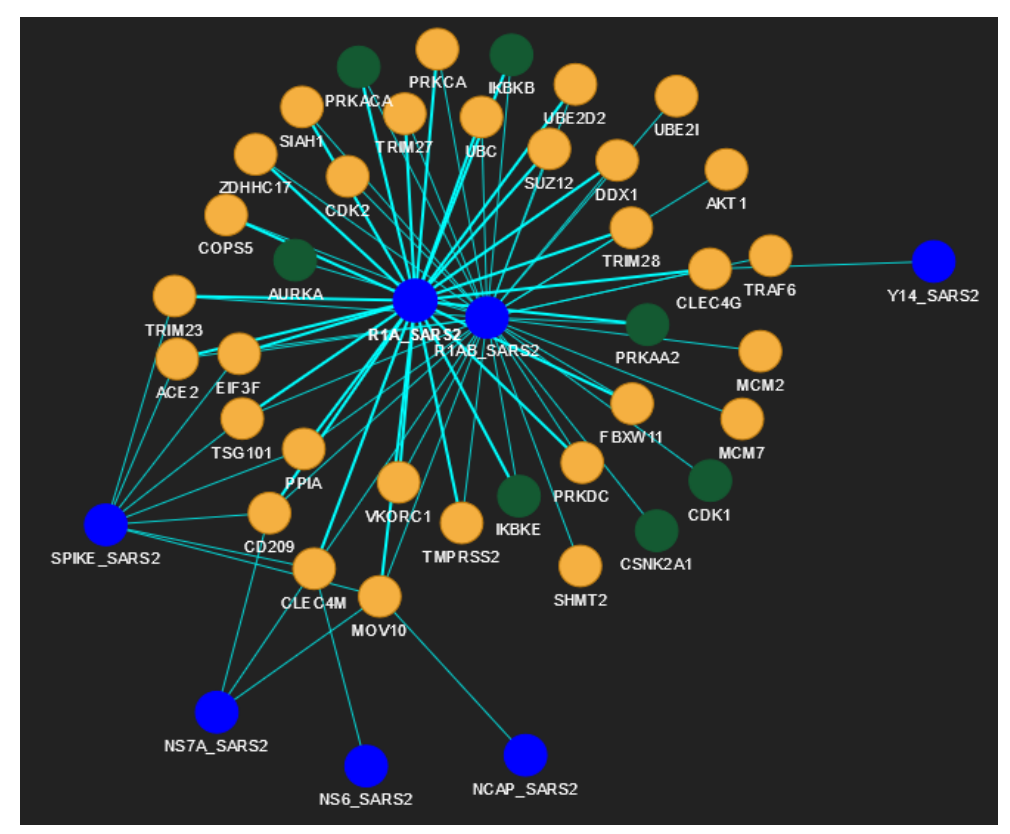

Figure 3 Application of PDS_CS algorithm in Human-CoV PPIN (level 1). DCS score of Fostamatinib in level 1 is 7 (green nodes). Blue and yellow nodes denote COVID19 and other level 1 proteins respectively.

\section{Results}

Computational study and results of associated drugs with human proteins in Human-nCoV PPIN shows that there is a probability that Fostamatinib may act as one of the potential candidates for COVID-19 treatment.

\section{Drug-consensus results for COVID-19 spreader nodes using Human-nCoV interaction network analysis}

Drugs along with their corresponding drug id are mapped with all level 1 and level 2 human spreader proteins of COVID19 by matching the corresponding drug protein targets with spreader nodes. It is observed after applying PDS_CS algorithm that Fostamatinib has a significant overlap of 155 target proteins in our Human-nCoV PPIN 
which is also the highest frequency of occurrence in the entire PPIN when compared to the remaining human protein associated drugs (i.e. highest DCS score as described earlier in methodology section). It has a DCS score of 7 (see Figure 3 and Table 4) and 148 (see Figure 4 and Table 5) in level 1 and level 2 human spreader proteins respectively.

Table 4 Detailed analysis of DCS score at level 1 (Top 5 DCS have been shown)

\begin{tabular}{|c|c|c|}
\hline Drug & Drug ID & DCS (Level 1) \\
\hline Fostamatinib & DB12010 & 7 \\
\hline Arsenic trioxide & DB01169 & 2 \\
\hline Acetylsalicylic acid & DB00945 & 2 \\
\hline Resveratrol & DB02709 & 2 \\
\hline Tamoxifen & DB00675 & 1 \\
\hline
\end{tabular}

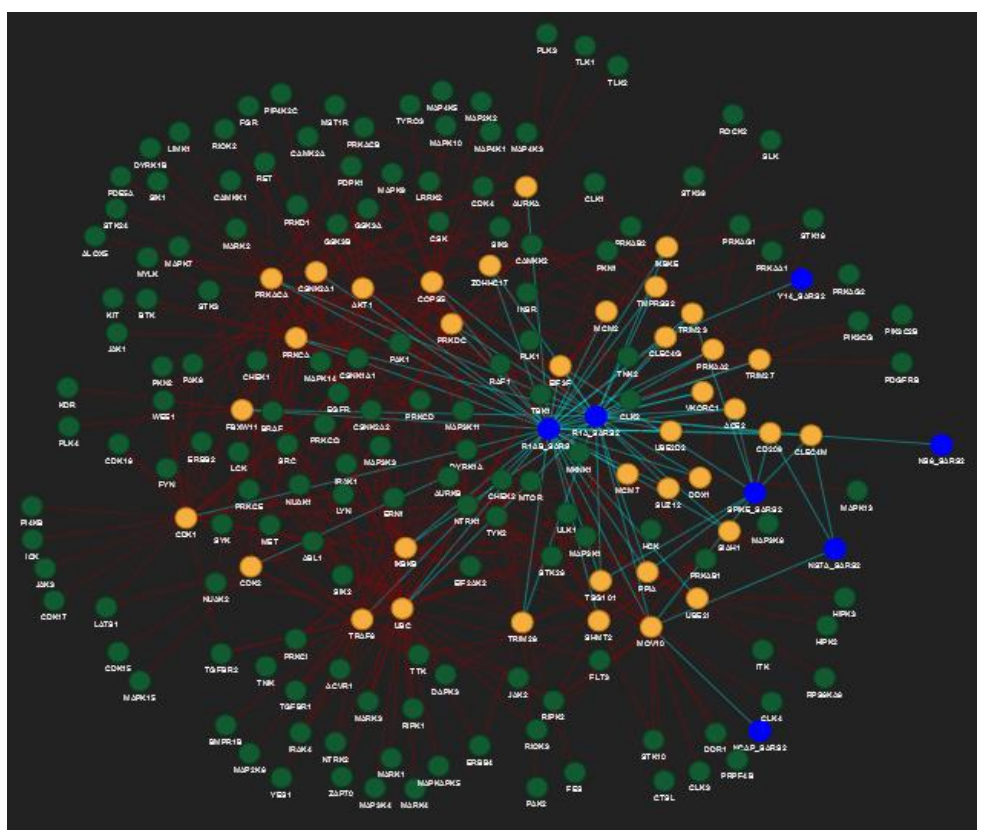

Figure 4 Application of PDS_CS algorithm in Human-CoV PPIN (level 2). DCS score of Fostamatinib in level 2 is 148 (green nodes). Blue and yellow nodes denote COVID19 and other level 1 spreader proteins respectively. Other level 2 spreaders are not shown to avoid visual complexity.

Table 5 Detailed analysis of DCS score at level 2 (Top 5 DCS have been shown)

\begin{tabular}{|c|c|c|}
\hline Drug & Drug ID & DCS (Level 2) \\
\hline Fostamatinib & DB12010 & 148 \\
\hline Copper & DB09130 & 88 \\
\hline Zinc acetate & DB14487 & 57 \\
\hline Zinc & DB01593 & 57 \\
\hline Zinc chloride & DB14533 & 57 \\
\hline
\end{tabular}

\section{Drug-consensus results for COVID-19 spreader nodes using COVID-19 symptoms, risk factors and clinical outcome based analysis}

Grouping of genes based on various categorizations of COVID-19 symptoms, risk factors and clinical outcome is done using DisGeNET ${ }^{42}$. The numerical statistics of the result is highlighted in Table 6. Molbiotools is used to compare these gene sets to obtain a gene set containing 4931 unique genes. These genes are further compared with curated COVID-19 dataset of CTD $^{44}$ which contains 12672 genes. The comparison generates an overlapping gene set containing 3525 genes. These genes when used for validation against our spreader proteins 
in Human-nCoV interaction network ${ }^{38}$, produces a significant overlap of 1448 genes in both level-1 and level-2. This highlights the fact that 1448 out of 3525 genes are selected as spreader nodes in our network. Hence top 10 key genes are selected from 1448 genes in each of both the levels based on the fuzzy score and spreadability index score in score in level-1 and level-2 respectively. The selected top genes from level-1 are PPIA, ACE2, EIF3F, UBC, PRKDC, CDK2, CDK1, AKT1, PRKCA and TRAF6 while the selected top genes from level-2 are APP, ELAVL1, NTRK1, XPO1, MEOX2, GRB2, EGFR, TP53, BAG3 and NXF1. Potential FDA drugs having these key genes/spreader proteins as known targets are identified from DrugBank data ${ }^{39,40}$ (see Table 7 and Table 8). It is also observed after applying PDS_CS algorithm on the obtained result in Table 7 and Table 8 that Fostamatinib has a significant overlap of 3 target proteins which is also the highest frequency of occurrence.

Table 6 Statistical analysis of genes in COVID-19 symptoms, risk factors and clinical outcome

\begin{tabular}{|c|c|c|}
\hline Categorizations & Symptoms & Total no. of genes \\
\hline \multirow{4}{*}{ COVID-19 symptoms ${ }^{41}$} & Cough & 270 \\
\hline & Fever & 1743 \\
\hline & Dyspnea & 323 \\
\hline & Pneumonia & 1416 \\
\hline \multirow{6}{*}{ Risk factors ${ }^{41}$} & Heart Disease & 1964 \\
\hline & Kidney Disease & 2131 \\
\hline & Lung Disease & 1018 \\
\hline & Diabetes & 5078 \\
\hline & Hypertension & 1573 \\
\hline & Cancer & 4747 \\
\hline \multirow{2}{*}{$\begin{array}{c}\text { Clinical Outcomes } \\
\text { (Mild \& Moderate Case) }^{41}\end{array}$} & Lymphopenia & 241 \\
\hline & Pulmonary infiltrate & 43 \\
\hline \multirow{7}{*}{ Clinical Outcomes (Severe Case) ${ }^{41}$} & Leukocytosis & 179 \\
\hline & Neutrophilia & 152 \\
\hline & Sepsis & 1506 \\
\hline & Kidney injury & 228 \\
\hline & Coagulopathy & 21 \\
\hline & Thrombocytopenia & 774 \\
\hline & Multiple organ failure & 25 \\
\hline
\end{tabular}

Table 7 Mapping of FDA drug of DrugBank with selected key genes of level-1

\begin{tabular}{|c|c|c|}
\hline \multirow{2}{*}{ Level-1 Key Genes } & \multicolumn{2}{|c|}{ Approved/Approved \& Investigational Drug } \\
\hline & Drug & Drug ID \\
\hline \multirow{2}{*}{ PPIA } & Cyclosporine & DB00091 \\
\hline & Copper & DB09130 \\
\hline \multirow{2}{*}{ ACE2 } & Hydroxychloroquine & DB01611 \\
\hline & Chloroquine & DB00608 \\
\hline EIF3F & \multicolumn{2}{|c|}{ No approved drug } \\
\hline UBC & \multicolumn{2}{|c|}{ No approved drug } \\
\hline PRKDC & Caffeine & DB00201 \\
\hline CDK2 & Bosutinib & DB06616 \\
\hline$C D K 1$ & Fostamatinib & $D B 12010$ \\
\hline \multirow{7}{*}{ PRKCA } & D-alpha-Tocopherol acetate & DB14002 \\
\hline & Midostaurin & DB06595 \\
\hline & alpha-Tocopherol succinate & DB14001 \\
\hline & Phosphatidyl serine & DB00144 \\
\hline & Vitamin E & DB00163 \\
\hline & Tamoxifen & DB00675 \\
\hline & Ingenol mebutate & DB05013 \\
\hline AKT1 & Arsenic trioxide & DB01169 \\
\hline TRAF6 & \multicolumn{2}{|c|}{ No approved drug } \\
\hline
\end{tabular}


Table 8 Mapping of FDA drug of DrugBank with selected key genes of level-2

\begin{tabular}{|c|c|c|}
\hline \multirow{2}{*}{ Level-2 Key Genes } & \multicolumn{2}{|c|}{ Approved/Approved \& Investigational Drug } \\
\hline & Drug & Drug ID \\
\hline \multirow{13}{*}{ APP } & Aluminium phosphate & DB14517 \\
\hline & Dimercaprol & DB06782 \\
\hline & Copper & DB09130 \\
\hline & Florbetapir (18F) & DB09149 \\
\hline & Flutemetamol (18F) & DB09151 \\
\hline & Deferoxamine & DB00746 \\
\hline & Zinc & DB01593 \\
\hline & Zinc sulfate, unspecified form & DB14548 \\
\hline & Florbetaben $(18 \mathrm{~F})$ & DB09148 \\
\hline & Zinc acetate & DB14487 \\
\hline & Aluminum acetate & DB14518 \\
\hline & Aluminium & DB01370 \\
\hline & Zinc chloride & DB14533 \\
\hline ELAVL1 & \multicolumn{2}{|c|}{ No approved drug } \\
\hline \multirow{7}{*}{ NTRK1 } & Entrectinib & DB11986 \\
\hline & Fostamatinib & DB12010 \\
\hline & Cenegermin & DB13926 \\
\hline & Amitriptyline & DB00321 \\
\hline & Imatinib & DB00619 \\
\hline & Regorafenib & DB08896 \\
\hline & Larotrectinib & DB14723 \\
\hline XPO1 & Selinexor & DB11942 \\
\hline MEOX2 & \multicolumn{2}{|c|}{ No approved drug } \\
\hline GRB2 & Pegademase & DB00061 \\
\hline \multirow{17}{*}{$E G F R$} & Lidocaine & DB00281 \\
\hline & Gefitinib & DB00317 \\
\hline & Fostamatinib & $D B 12010$ \\
\hline & Zanubrutinib & DB15035 \\
\hline & Cetuximab & DB00002 \\
\hline & Erlotinib & DB00530 \\
\hline & Vandetanib & DB05294 \\
\hline & Osimertinib & DB09330 \\
\hline & Dacomitinib & DB11963 \\
\hline & Brigatinib & DB12267 \\
\hline & Foreskin keratinocyte (neonatal) & DB10772 \\
\hline & Trastuzumab & DB00072 \\
\hline & Lapatinib & DB01259 \\
\hline & Panitumumab & DB01269 \\
\hline & Afatinib & DB08916 \\
\hline & Necitumumab & DB09559 \\
\hline & Neratinib & DB11828 \\
\hline \multirow{5}{*}{ TP53 } & Zinc acetate & DB14487 \\
\hline & Zinc chloride & DB14533 \\
\hline & Acetylsalicylic acid & DB00945 \\
\hline & Zinc & DB01593 \\
\hline & Zinc sulfate, unspecified form & DB14548 \\
\hline BAG3 & \multicolumn{2}{|c|}{ No approved drug } \\
\hline NXF1 & \multicolumn{2}{|c|}{ No approved drug } \\
\hline
\end{tabular}

\section{Docking results for potential COVID-19 drugs with respect to 6LU7}

Molecular docking is used in the proposed methodology to measure the binding capability of the potential COVID19 drugs on 6LU7, the crystal structure of COVID-19 main protease. The detailed procedure of execution has been already discussed in methodology section. In this work, SDF format (3D conformer) is used for the docking of all the COVID19 drugs. All the results of docking are highlighted in Table 9. It can be observed from Table 9, that Fostamatinib shows high binding affinity scores in comparison to remdesivir, 
hydroxychloroquine, favipiravir, darunavir, azithromycin, lopinavir and ritonavir. Docking has been also performed between 6LU7 and the mapped FDA drugs of key genes in level-1 and level-2 (see Table 7 and Table 8), the result of which has been shown in Table 10. It also proves the fact that Fostamatinib has the highest docking score.

\section{Docking results for active metabolites/promoieties of COVID-19 Prodrugs with respect to 6LU7}

Several drug molecules consist of pharmacologically inactive compounds which are known as Prodrugs ${ }^{80}$. These drugs get metabolized after entering in human body to liberate the active drug. On careful observation, it has been noted that Fostamatinib is also a prodrug. Fostamatinib (R788) is considered to be an orally induced prodrug in human which releases active metabolite/promoiety R940406 (R406) ${ }^{81}$. R406 is a spleen tyrosine kinase (SYK) inhibitor, which is responsible for the treatment of rheumatoid arthritis ${ }^{81}$. Similar instances have been also observed in the case of remdesivir and favipiravir. So the binding capability of these active metabolites/promoieties also needs to be validated against 6LU7 by molecular docking for consideration of any prodrug as a COVID19 drug. The results of this docking are depicted in Table 11. It can be inferred from Table 11 that R406 also shows high binding affinity scores in comparison to the others which in turn promotes the fact that Fostamatinib can be a potential COVID19 drug. Molecular docking results of Fostamatinib and its corresponding promoiety, R406 have been also highlighted in Figure 5.

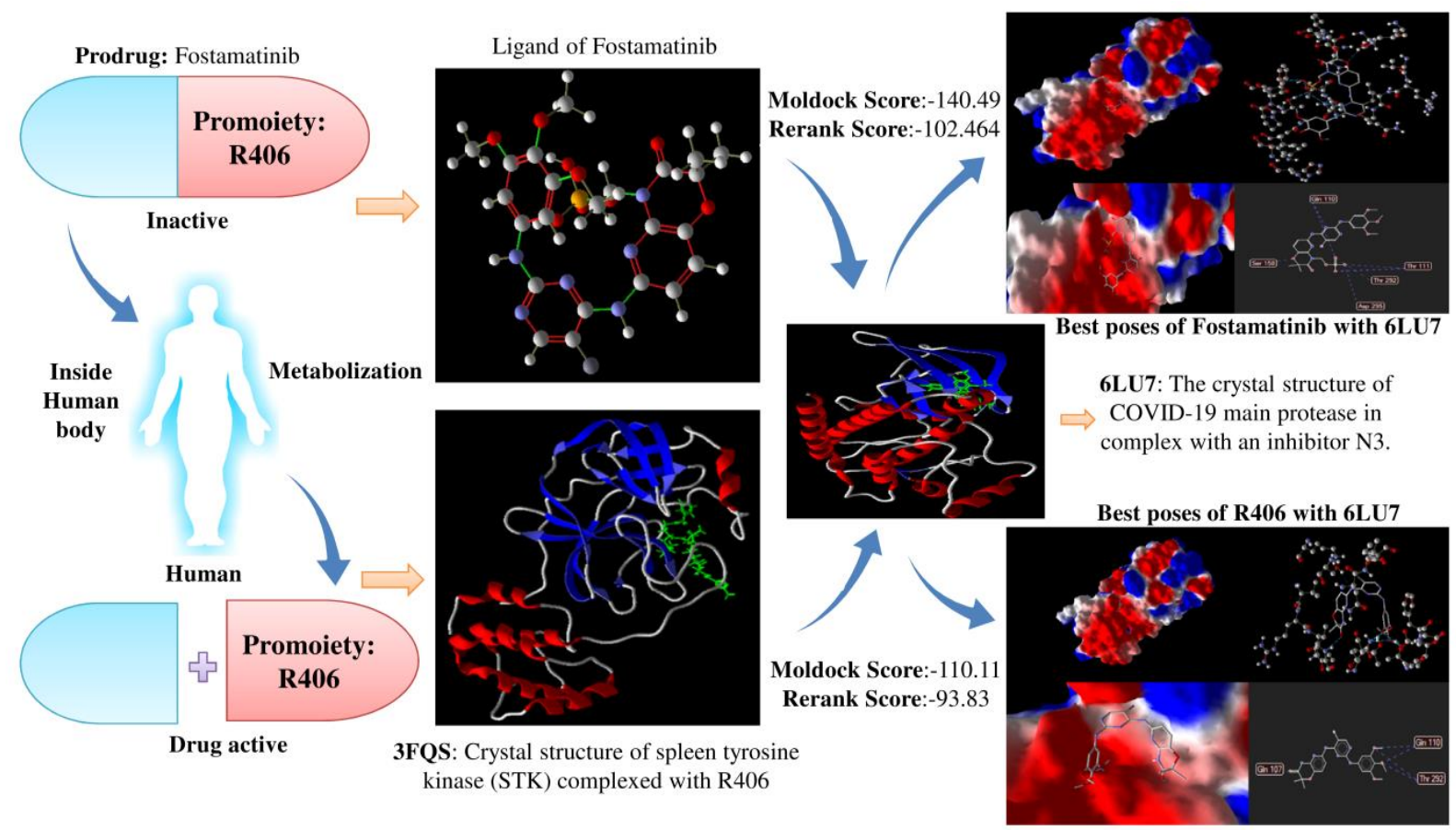

Figure 5 Molecular docking results of prodrug Fostamatinib and its corresponding promoiety, R406. Fostamatinib and R406 both have high binding affinity scores in comparison to the other potential COVID19 drugs. 
Table 9 Best dock poses for potential COVID19 drugs and interactions of hydrogen bonds with respect to 6LU7

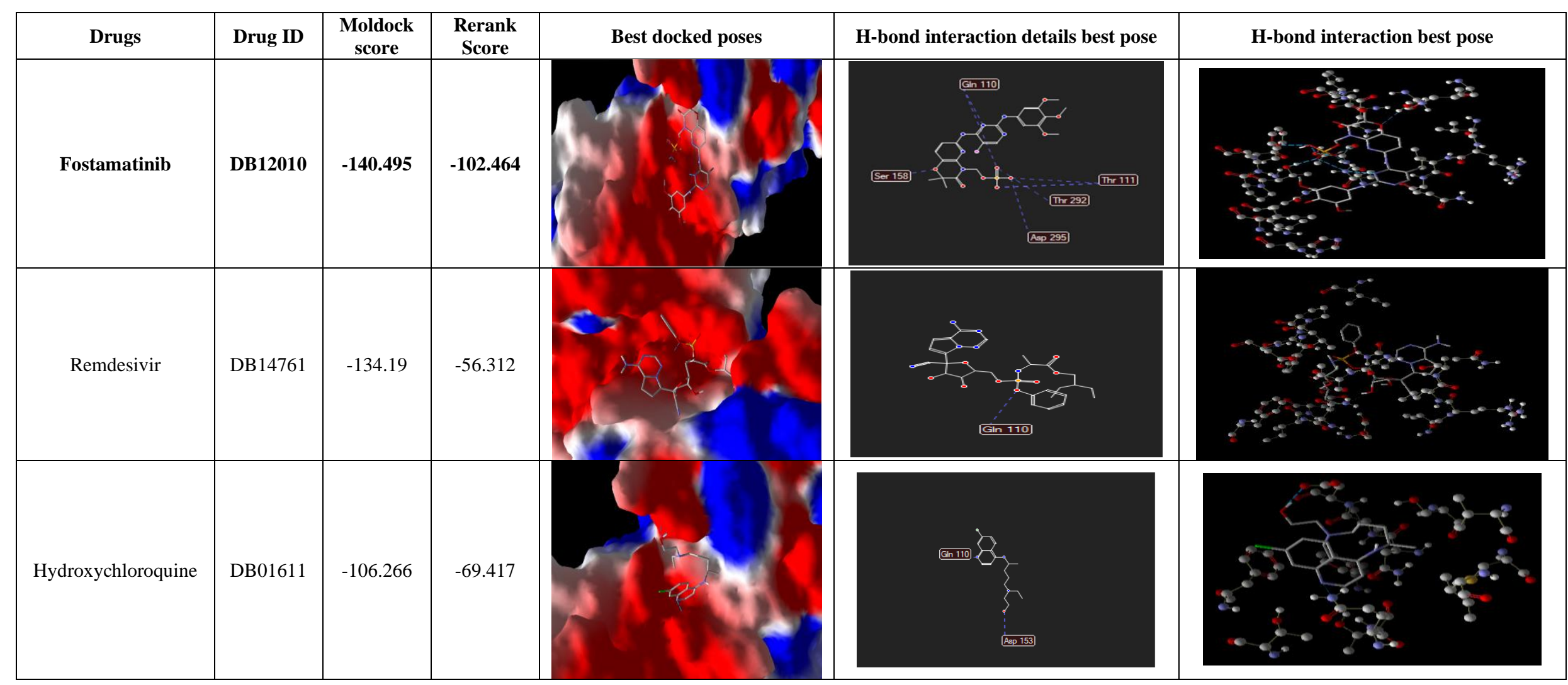




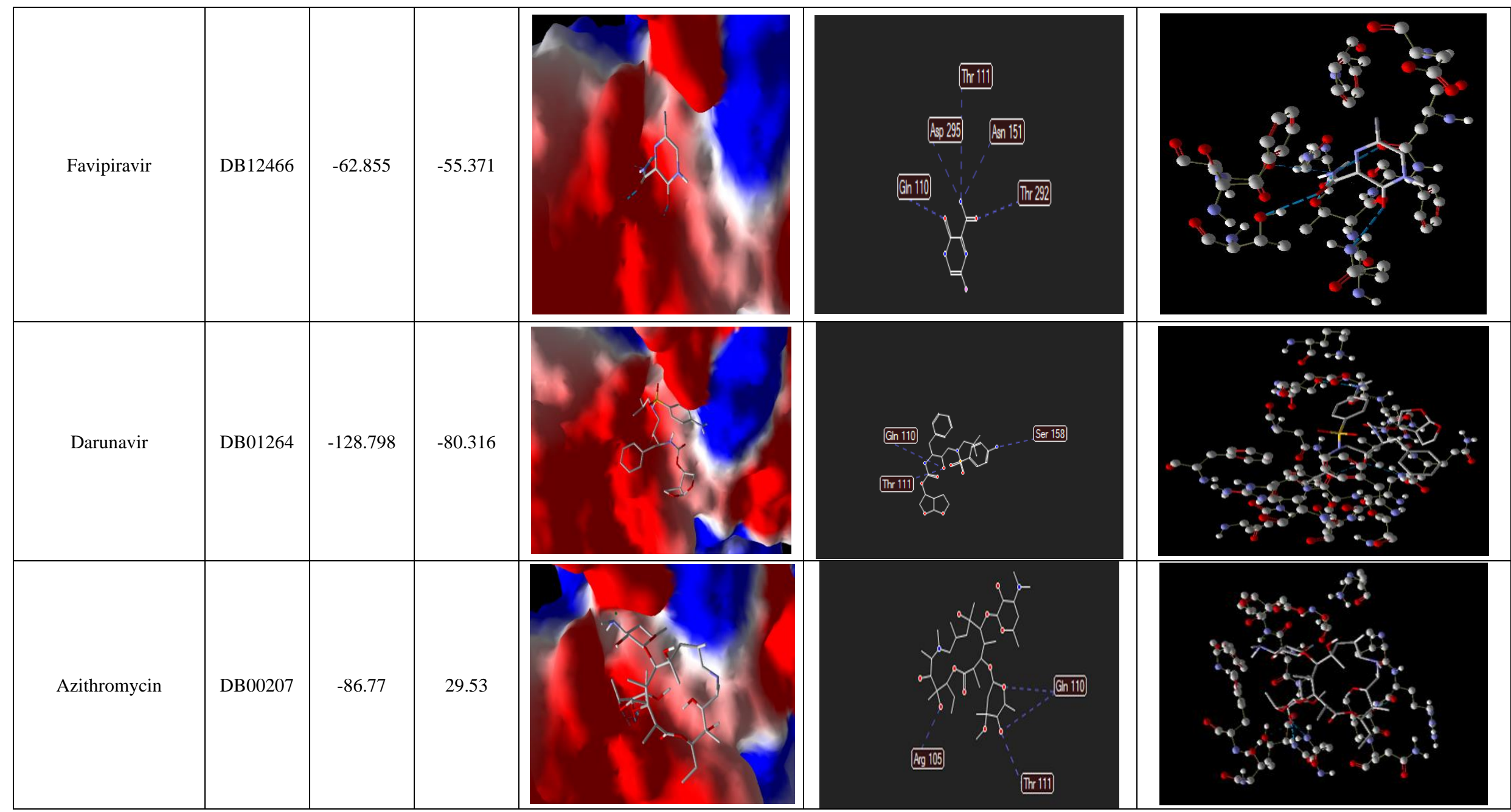




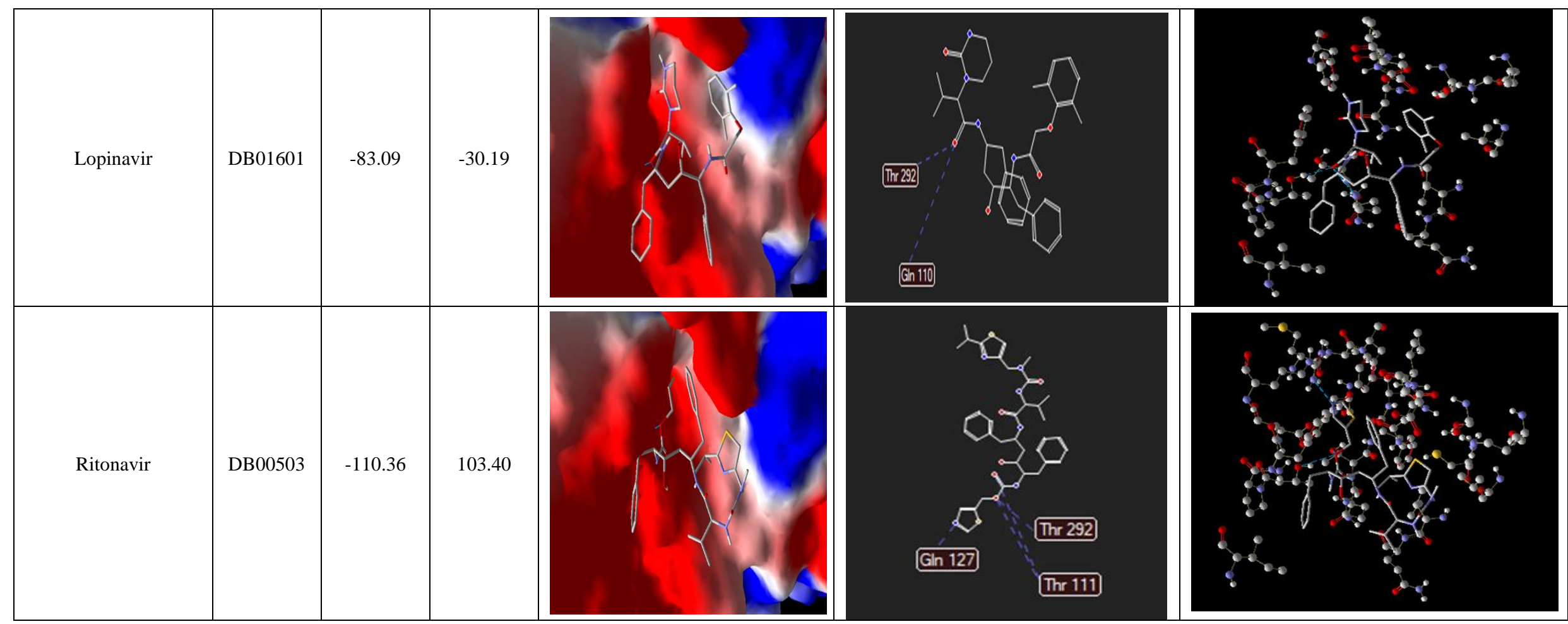


Table 10 Docking scores between 6LU7 and the mapped FDA drugs of key genes in level-1 and level-2

\begin{tabular}{|c|c|c|c|}
\hline Drug & Drug ID & Moldock Score & Rerank Score \\
\hline Fostamatinib & DB12010 & $\mathbf{- 1 4 0 . 4 9 5}$ & $\mathbf{- 1 0 2 . 4 6 4}$ \\
\hline Larotrectinib & DB14723 & -140.477 & -96.833 \\
\hline Selinexor & DB11942 & -137.622 & -95.531 \\
\hline Regorafenib & DB08896 & -136.333 & -87.952 \\
\hline Lapatinib & DB01259 & -132.411 & -77.797 \\
\hline Osimertinib & DB09330 & -128.307 & -71.159 \\
\hline Bosutinib & DB06616 & -128.113 & -31.981 \\
\hline Imatinib & DB00619 & -126.843 & -36.034 \\
\hline Gefitinib & DB00317 & -126.808 & -87.68 \\
\hline Neratinib & DB11828 & -125.872 & -73.871 \\
\hline Afatinib & DB08916 & -125.727 & -31.114 \\
\hline Cyclosporine & DB00091 & -119.025 & -4.147 \\
\hline Vandetanib & DB05294 & -117.197 & -76.946 \\
\hline Dacomitinib & DB11963 & -116.462 & 73.271 \\
\hline Zanubrutinib & DB15035 & -115.673 & -72.988 \\
\hline Erlotinib & DB00530 & -113.65 & 77.383 \\
\hline Florbetaben (18F) & DB09148 & -111.68 & -75.998 \\
\hline Deferoxamine & DB00746 & -111.072 & 0.394 \\
\hline Florbetapir (18F) & DB09149 & -108.564 & -81.287 \\
\hline Entrectinib & DB11986 & -91.681 & 346.912 \\
\hline Flutemetamol (18F) & DB15058 & -85.347 & -70.097 \\
\hline Brigatinib & DB12267 & -80.187 & 271.203 \\
\hline Amitriptyline & DB00321 & -75.386 & -96.042 \\
\hline Lidocaine & DB00281 & -65.781 & -34.584 \\
\hline Caffeine & DB00201 & -60.617 & -55.691 \\
\hline Dimercaprol & DB06782 & -39.003 \\
\hline Copper & DB09130 & -46.439 & -27.328 \\
\hline Midostaurin & DB06595 & -28.861 & -84.857 \\
\hline Tamoxifen & DB00675 & -86.346 & \\
\hline & & -123.549 & \\
\hline
\end{tabular}


Table 11 Best dock poses for active metabolites/promoieties of potential COVID-19 prodrugs with respect to 6LU7

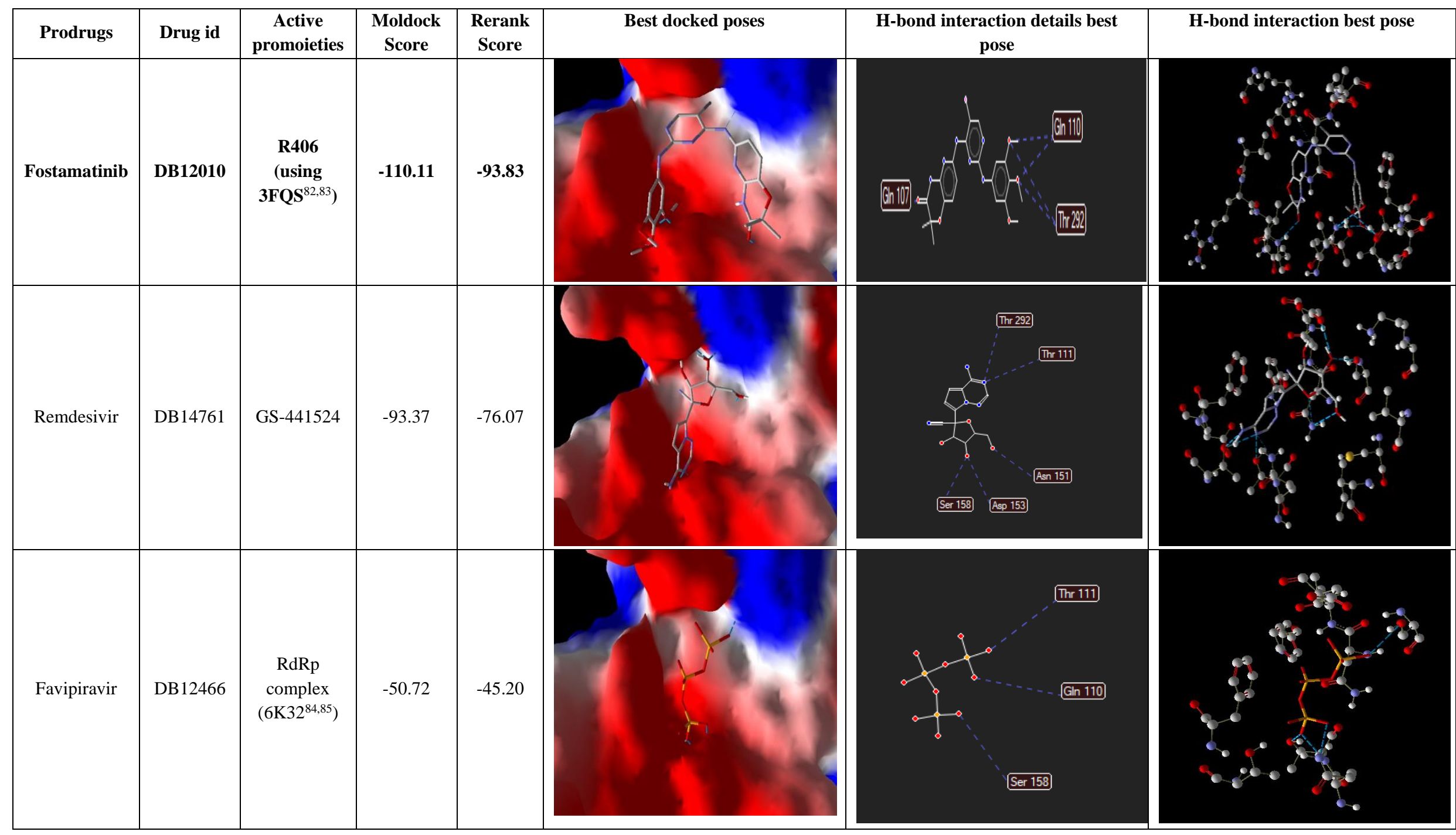




\section{Analysis of 3 key target genes of Fostamatinib identified in level-1 and level-2 of Human-nCoV interaction network in COVID-19 symptoms, risk factors and clinical outcome based analysis}

The three key target genes of Fostamatinib as identified in Table 7 and Table 8, are CDK1 (level-1) and NTRK1, EGFR (level-2). On careful observation, it has been noted that these three genes are related to the most significant COVID-19 symptoms, risk factors and clinical outcomes which are highlighted in Table 12. Moreover, these 3 genes also play an important role in response to the viral infections (see Table 13). All these depict the fact that Fostamatinib might be a potential drug treatment to COVID-19 treatment.

Table 12 Mapping of CDK1 and NTRK1, EGFR with COVID-19 symptoms, risk factors and clinical outcomes

\begin{tabular}{|c|c|c|c|c|c|}
\hline Drug & Key Target Genes & Level & $\begin{array}{l}\text { COVID-19 } \\
\text { symptoms }\end{array}$ & $\begin{array}{l}\text { Clinical outcome } \\
\text { (severe case) }\end{array}$ & Risk Factor \\
\hline \multirow{13}{*}{ Fostamatinib } & \multirow{2}{*}{ CDK1 } & \multirow{2}{*}{ Level-1 } & \multirow{2}{*}{ pneumonia } & \multirow{2}{*}{--} & diabetes \\
\hline & & & & & cancer \\
\hline & \multirow{5}{*}{ NTRK1 } & \multirow{5}{*}{ Level-2 } & \multirow{3}{*}{ fever } & \multirow{5}{*}{--} & kidney disease \\
\hline & & & & & cancer \\
\hline & & & & & hypertension \\
\hline & & & \multirow{2}{*}{ pneumonia } & & lung disease \\
\hline & & & & & diabetes \\
\hline & \multirow{6}{*}{ EGFR } & \multirow{6}{*}{ Level-2 } & \multirow{3}{*}{ pneumonia } & \multirow{4}{*}{ neutrophilia } & heart disease \\
\hline & & & & & hypertension \\
\hline & & & & & cancer \\
\hline & & & dyspnea & & kidney disease \\
\hline & & & fever & kidney injury & lung disease \\
\hline & & & cough & thrombocytopenia & diabetes \\
\hline
\end{tabular}

Table 13 Role of CDK1 and NTRK1, EGFR in viral infections

\begin{tabular}{|c|c|c|c|}
\hline Drug & Key Target Genes & Level & $\begin{array}{l}\text { Role in viral infections } \\
\end{array}$ \\
\hline \multirow{3}{*}{ Fostamatinib } & CDK1 & Level-1 & $\begin{array}{l}\text { Viruses have the capability to express some onco-proteins. These } \\
\text { proteins could interfere with CDK and CIKs function, along with the } \\
\text { induction of some signals which will lead to the replication of their } \\
\text { genome inside the cells of the hosts }{ }^{6} \text {. }\end{array}$ \\
\hline & NTRK1 & Level-2 & $\begin{array}{ll}\text { NTRK1 has an active role in defence response }{ }^{87} \text { to: } \\
\text { 1. } & \text { Neutrophil mediated immunity against viral infection }{ }^{87} . \\
2 . & \text { Inflammatory response to wounding }^{87} . \\
3 . & \text { Bacterium }^{87} . \\
\end{array}$ \\
\hline & EGFR & Level-2 & $\begin{array}{l}\text { Inhibition of EGFR signalling might lead to the prevention of an } \\
\text { excessive fibrotic response to SARS-CoV and other respiratory viral } \\
\text { infections.7 }\end{array}$ \\
\hline
\end{tabular}

\section{Other significant studies}

Drug interactions of genes have been also significantly studied and two online resources: STITCH $^{88,89}$ and DGIdb $^{90}$ are used to fetch the corresponding interactive drugs/chemicals of the selected top key genes (as shown in Table 7 and Table 8) in level-1 and level-2 of Human-nCoV interaction network (see Table 14 and Table 15). In STITCH, top 10 drug interactions having high threshold (greater than 0.9 ) have been shown while in DGIdb, top 10 drug interactions having high interaction scores have been highlighted. It is to be noted here that the drugs like cyclosporine etc. involved in the interaction of these key genes should be also considered for COVID19 treatment since these genes are found to play an active role in COVID-19 $\operatorname{transmission}^{68-72}$ as well as in its prevention ${ }^{73-77}$. 
Table 14 Level 1 key gene-drug interaction analysis

\begin{tabular}{|c|c|c|c|c|c|}
\hline \multirow{2}{*}{$\begin{array}{c}\text { Level-1 } \\
\text { Key } \\
\text { Genes }\end{array}$} & \multicolumn{2}{|c|}{ STITCH $^{88,89}$} & \multicolumn{3}{|c|}{ DGIdb $^{90}$} \\
\hline & $\begin{array}{l}\text { FDA approved } \\
\text { Drug/chemical }\end{array}$ & $\begin{array}{c}\text { Network } \\
\text { interaction } \\
\text { score }(>0.9)\end{array}$ & FDA approved Drug & Interaction Type & Score \\
\hline \multirow{5}{*}{ PPIA } & cyclosporine & 0.984 & \multirow{5}{*}{ cyclosporine } & \multirow{5}{*}{ inhibitor, modulator } & \multirow{5}{*}{11} \\
\hline & calcium ions & 0.980 & & & \\
\hline & fe(iii & 0.979 & & & \\
\hline & zn(ii & 0.979 & & & \\
\hline & 3h-proline & 0.976 & & & \\
\hline \multirow{7}{*}{ ACE2 } & losartan & 0.990 & lisinopril & inhibitor & 6 \\
\hline & captopril & 0.989 & \multirow{6}{*}{ flutamide } & \multirow{6}{*}{ N/A } & \multirow{6}{*}{1} \\
\hline & lisinopril & 0.990 & & & \\
\hline & enalaprilat & 0.983 & & & \\
\hline & $m \ln -4760$ & 0.982 & & & \\
\hline & angiotensin-(1-7 & 0.980 & & & \\
\hline & chloride & 0.979 & & & \\
\hline \multirow{10}{*}{ CDK2 } & roscovitine & 0.997 & paclitaxel & N/A & 2 \\
\hline & staurosporine & 0.997 & daunorubicin & N/A & 2 \\
\hline & MgATP & 0.991 & lovastatin & N/A & 2 \\
\hline & phosphate & 0.986 & eribulin & N/A & 2 \\
\hline & & & hydrogen peroxide & N/A & 2 \\
\hline & & & acetaminophen & N/A & 2 \\
\hline & & & bosutinib & inhibitor & 2 \\
\hline & & & raltitrexed & N/A & 2 \\
\hline & & & dexamethasone & N/A & 2 \\
\hline & & & carboplatin & N/A & 2 \\
\hline \multirow{4}{*}{ CDK1 } & flavopiridol & 0.990 & eltrombopag & agonist & 1 \\
\hline & aminopurvalanol a & 0.997 & \multirow{3}{*}{ romiplostim } & \multirow{3}{*}{ agonist } & \multirow{3}{*}{1} \\
\hline & dinaciclib & 0.971 & & & \\
\hline & purvalanol & 0.970 & & & \\
\hline \multirow{10}{*}{ AKT1 } & \multirow{5}{*}{ rapamycin } & \multirow{5}{*}{0.996} & arsenic trioxide & inducer & 6 \\
\hline & & & everolimus & inhibitor & 3 \\
\hline & & & vemurafenib & N/A & 3 \\
\hline & & & irinotecan & N/A & 2 \\
\hline & & & doxorubicin & N/A & 2 \\
\hline & $\begin{array}{c}\text { mk-2206 } \\
\text { dihydrochloride }\end{array}$ & 0.996 & sirolimus & N/A & 2 \\
\hline & MgATP & 0.993 & temsirolimus & N/A & 2 \\
\hline & azd5363 & 0.992 & cetuximab & N/A & 2 \\
\hline & & & paclitaxel & N/A & 1 \\
\hline & & & sorafenib & N/A & 1 \\
\hline \multirow{4}{*}{ EIF3F } & phosphate & 0.952 & \multirow{4}{*}{\multicolumn{3}{|c|}{ No interactions with FDA approved drugs found. }} \\
\hline & MgADP & 0.900 & & & \\
\hline & MgATP & 0.900 & & & \\
\hline & $\begin{array}{c}\text { guanosine } \\
\text { diphosphate }\end{array}$ & 0.900 & & & \\
\hline & $\mathrm{zn}(\mathrm{ii}$ & 0.983 & & & \\
\hline $\mathrm{URC}$ & 3h-proline & 0.950 & No interactions wi & FDA annroved drugs & nd \\
\hline UBC & arginine & 0.934 & No interactions w1 & FDA approved drugs & nd. \\
\hline & methionine & 0.933 & & & \\
\hline & MgATP & 0.992 & & & \\
\hline PPKDC & wortmannin & 0.945 & & & \\
\hline PRKDL & dna-pk inhibitor ii & 0.928 & No interactions w1 & FDA approved drugs & nd. \\
\hline & torin 2 & 0.901 & & & \\
\hline
\end{tabular}




\begin{tabular}{|c|c|c|c|c|c|}
\hline \multirow{4}{*}{ TRAF6 } & MgATP & 0.915 & \multirow{3}{*}{\multicolumn{3}{|c|}{ No interactions with FDA approved drugs found. }} \\
\hline & MgADP & 0.900 & & & \\
\hline & $\begin{array}{c}\text { adenosine } \\
\text { monophosphate }\end{array}$ & 0.900 & & & \\
\hline & pyrophosphate & 0.900 & & & \\
\hline \multirow{3}{*}{ PRKCA } & MgATP & 0.900 & vitamin e & N/A & 6 \\
\hline & MgADP & 0.900 & ingenol mebutate & activator, ligand & 4 \\
\hline & calcium ions & 0.900 & tamoxifen & N/A & 2 \\
\hline
\end{tabular}

Table 15 Level 2 key gene-drug interaction analysis

\begin{tabular}{|c|c|c|c|c|c|}
\hline \multirow[b]{2}{*}{$\begin{array}{l}\text { Key } \\
\text { Genes }\end{array}$} & \multicolumn{2}{|c|}{ STITCH $^{88,89}$} & \multicolumn{3}{|c|}{ DGIdb $^{90}$} \\
\hline & $\begin{array}{c}\text { FDA } \\
\text { approved } \\
\text { Drug/chemical }\end{array}$ & $\begin{array}{c}\text { Network } \\
\text { interaction } \\
\text { score }(>0.9)\end{array}$ & FDA approved Drug & Interaction Type & Score \\
\hline \multirow{6}{*}{ APP } & \multirow{6}{*}{ calcium ions } & \multirow{6}{*}{0.994} & flutemetamol f18 & binder & 2 \\
\hline & & & propofol & $\mathrm{N} / \mathrm{A}$ & 2 \\
\hline & & & daunorubicin & N/A & 2 \\
\hline & & & hydroxychloroquine & N/A & 2 \\
\hline & & & florbetapir f 18 & binder & 2 \\
\hline & & & [18f] florbetaben & binder & 1 \\
\hline \multirow{10}{*}{ NTRK1 } & \multirow{5}{*}{$\begin{array}{l}\text { antibiotic SF- } \\
2370\end{array}$} & \multirow{5}{*}{0.996} & interferon gama- $1 \mathrm{~b}$ & N/A & 3 \\
\hline & & & crizotinib & N/A & 3 \\
\hline & & & cytarabine & N/A & 2 \\
\hline & & & acetylcysteine & N/A & 2 \\
\hline & & & phenylephrine & N/A & 2 \\
\hline & \multirow{5}{*}{ lestaurtinib } & \multirow{5}{*}{0.996} & regorafenib & inhibitor & 2 \\
\hline & & & imatinib & N/A & 2 \\
\hline & & & estradiol & N/A & 2 \\
\hline & & & pyridoxine & N/A & 2 \\
\hline & & & tamoxifen & N/A & 2 \\
\hline \multirow{4}{*}{ GRB2 } & $\begin{array}{l}\text { guanosine } \\
\text { triphosphate }\end{array}$ & 0.942 & pegademase bovine & binder & 2 \\
\hline & cadmium & 0.929 & \multirow{3}{*}{ dactinomycin } & \multirow{3}{*}{ N/A } & \multirow{3}{*}{2} \\
\hline & AC1LCW0V & 0.915 & & & \\
\hline & $\begin{array}{l}\text { guanosine } \\
\text { diphosphate }\end{array}$ & 0.907 & & & \\
\hline \multirow{10}{*}{ EGFR } & \multirow{2}{*}{ gefitinib } & \multirow{2}{*}{0.999} & erlotinib & antagonist, inhibitor & 167 \\
\hline & & & afatinib & inhibitor & 141 \\
\hline & \multirow[b]{2}{*}{ erlotinib } & \multirow[b]{2}{*}{0.999} & gefitinib & antagonist, inhibitor & 125 \\
\hline & & & cetuximab & $\begin{array}{c}\text { antagonist, inhibitor, } \\
\text { antibody }\end{array}$ & 110 \\
\hline & \multirow[t]{2}{*}{ afatinib } & \multirow[t]{2}{*}{0.999} & panitumumab & $\begin{array}{l}\text { agonist, inhibitor, } \\
\text { antibody, suppressor }\end{array}$ & 32 \\
\hline & & & lapatinib & antagonist, inhibitor & 31 \\
\hline & \multirow{4}{*}{ lapatinib } & \multirow{4}{*}{0.999} & osimertinib & inhibitor & 31 \\
\hline & & & vandetanib & inhibitor & 12 \\
\hline & & & sirolimus & N/A & 8 \\
\hline & & & necitumumab & $\begin{array}{c}\text { antagonist, inhibitor, } \\
\text { antibody }\end{array}$ & 7 \\
\hline \multirow{6}{*}{ TP53 } & \multirow{2}{*}{ etoposide } & \multirow{2}{*}{0.993} & doxorubicin & N/A & 10 \\
\hline & & & bevacizumab & N/A & 8 \\
\hline & MrATP & 0091 & gemcitabine & N/A & 7 \\
\hline & VIgA IP & 0.991 & carboplatin & N/A & 7 \\
\hline & 5-fluorouracil & 0991 & paclitaxel & N/A & 4 \\
\hline & J-Iluorouracil & 0.991 & docetaxel & N/A & 4 \\
\hline
\end{tabular}




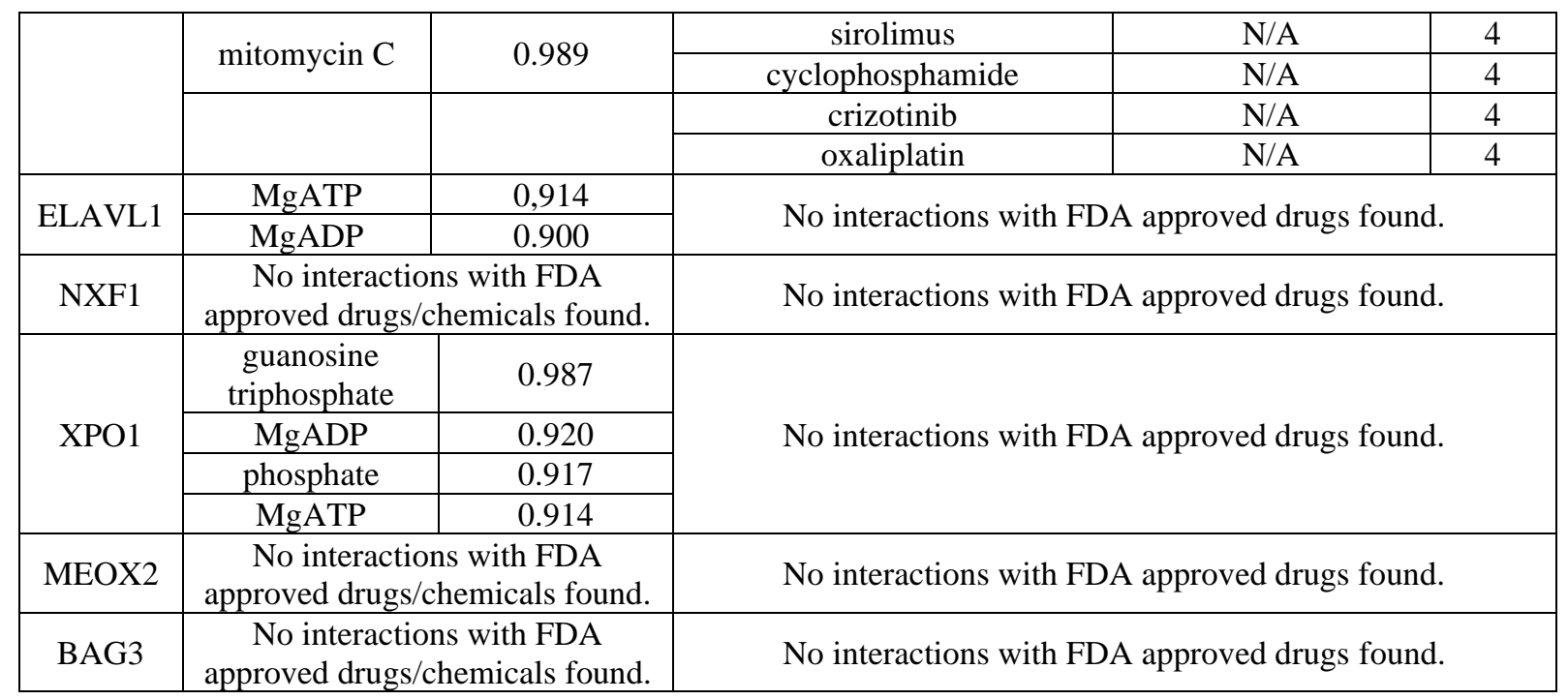

\section{Application of Algorithm S1 (PDS_CS) on in the host targets of in vitro generated Human-nCoV PPIN of Gordon et al. ${ }^{91}$.}

Gordon et al. ${ }^{91}$ cloned, tagged and expressed 26 of the 29 SARS-CoV-2 proteins in human cells and identified the human proteins that physically associated with each of the SARS-CoV-2 proteins using affinity-purification mass spectrometry, identifying 332 high-confidence protein-protein interactions between SARS-CoV-2 and human proteins. These 332 host targets are collected and Algorithm S1 (PDS_CS) is implemented on the same. It is observed from the implementation that Fostamatinib/R406 has a significant overlap of 10 target proteins (i.e., DCS score of 10) in Human-nCoV PPIN which is also the highest frequency of occurrence in the entire PPIN when compared to the remaining human protein associated drugs. The result is highlighted in the below table.

Detailed analysis of DCS score (Top 6 DCS have been shown)

\begin{tabular}{|c|c|c|}
\hline Drug & Drug ID & DCS (Level 1) \\
\hline Fostamatinib & DB12010 & 10 \\
\hline NADH & DB00157 & 5 \\
\hline Flavin adenine dinucleotide & DB03147 & 5 \\
\hline Romidepsin & DB06176 & 2 \\
\hline Glutamic acid & DB00142 & 2 \\
\hline Atorvastatin & DB01076 & 1 \\
\hline
\end{tabular}

\section{Conclusion}

In this computational study, we have analyzed the Human-nCoV PPIN and attempted to identify the candidate drugs for the level-1 and level-2 spreader proteins. Our study identifies Fostamatinib, a FDA approved drug, as the most promising drug with best chances to target the COVID-19 spreader proteins. This drug may be considered as a potential candidate for COVID-19 treatment and related clinical trials.

Our work relies on the hypothesis that SARS-CoV $2 / \mathrm{nCoV}$ is believed to have $\sim 89 \%$ genetic resemblance with SARS-CoV. Based on this, we have developed Human-nCoV PPIN by the identification of spreader nodes using SIS model and fuzzy thresholding. A consensus strategy by a two-way analysis has been utilized to analyze drugs based on the overlap of spreader proteins and drug protein targets. The consensus scores for Fostamatinib are highest in both the analysis among the candidate drugs for COVID-19 spreader proteins. Besides, it also generates the best results in molecular docking with the available COVID19 protein structures. These findings affirm that Fostamatinib might be one of the candidate drugs on COVID19, and worth a thorough clinical trial. Fostamatinib also targets CAYP34A ${ }^{46,47}$, a common target for almost all the FDA approved drugs ${ }^{34}$ for COVID-19. Moreover, recent studies also suggest that Fostamatinib is used for 
thrombocytopenia ${ }^{46}$ which is also associated with severe coronavirus disease 2019 (COVID-19) infections ${ }^{48}$. In a nutshell, our computational research evidences discover the fact that Fostamatinib may be considered as one of the strong contenders for COVID-19 treatment and necessary trials may be initiated for clinical validations.

\section{References}

1. Modes of transmission of virus causing COVID-19: implications for IPC precaution recommendations. https://www.who.int/news-room/commentaries/detail/modes-of-transmission-of-virus-causing-covid-19implications-for-ipc-precaution-recommendations.

2. Li, G. \& De Clercq, E. Therapeutic options for the 2019 novel coronavirus (2019-nCoV). Nature reviews. Drug discovery vol. 19 149-150 (2020).

3. WHO Coronavirus Disease (COVID-19) Dashboard. https://covid19.who.int/.

4. Cortegiani, A., Ingoglia, G., Ippolito, M., Giarratano, A. \& Einav, S. A systematic review on the efficacy and safety of chloroquine for the treatment of COVID-19. J. Crit. Care (2020) doi:10.1016/j.jcrc.2020.03.005.

5. Zhang, Q., Wang, Y., Qi, C., Shen, L. \& Li, J. Clinical trial analysis of 2019-nCoV therapy registered in China. J. Med. Virol. 92, 540-545 (2020).

6. Rabby, M. I. I. Current drugs with potential for treatment of covid-19: A literature review. J. Pharm. Pharm. Sci. 23, 58-64 (2020).

7. Zhang, W. et al. The use of anti-inflammatory drugs in the treatment of people with severe coronavirus disease 2019 (COVID-19): The experience of clinical immunologists from China. Clinical Immunology vol. 214 (2020).

8. Gautret, P. et al. Hydroxychloroquine and azithromycin as a treatment of COVID-19: results of an open-label nonrandomized clinical trial. Int. J. Antimicrob. Agents 105949 (2020) doi:10.1016/j.ijantimicag.2020.105949.

9. Runfeng, L. et al. Lianhuaqingwen exerts anti-viral and anti-inflammatory activity against novel coronavirus (SARS-CoV-2). Pharmacol. Res. 156, 104761 (2020).

10. Liu, J. et al. Hydroxychloroquine, a less toxic derivative of chloroquine, is effective in inhibiting SARS-CoV-2 infection in vitro. Cell Discovery vol. 6 1-4 (2020).

11. Sahraei, Z., Shabani, M., Shokouhi, S. \& Saffaei, A. Aminoquinolines against coronavirus disease 2019 (COVID19): chloroquine or hydroxychloroquine. Int. J. Antimicrob. Agents 55, (2020).

12. Cai, Q. et al. Experimental Treatment with Favipiravir for COVID-19: An Open-Label Control Study. Engineering (2020) doi:10.1016/j.eng.2020.03.007.

13. Wu, D. \& Yang, X. O. TH17 responses in cytokine storm of COVID-19: An emerging target of JAK2 inhibitor Fedratinib. J. Microbiol. Immunol. Infect. (2020) doi:10.1016/j.jmii.2020.03.005.

14. Yao, X. et al. In Vitro Antiviral Activity and Projection of Optimized Dosing Design of Hydroxychloroquine for the Treatment of Severe Acute Respiratory Syndrome Main point: Hydroxychloroquine was found to be more potent than chloroquine at inhibiting SARS-CoV-2 in vit. Clin. Infect. Dis. 2, 1-25 (2020).

15. Tang, B. et al. Coronavirus Disease 2019 (COVID-19) Pneumonia in a Hemodialysis Patient. Kidney Med. (2020) doi:10.1016/j.xkme.2020.03.001.

16. Fan, H. H. et al. Repurposing of clinically approved drugs for treatment of coronavirus disease 2019 in a 2019 novel coronavirus (2019-nCoV) related coronavirus model. Chin. Med. J. (Engl). 133, (2020).

17. Ren, J. ling, Zhang, A. H. \& Wang, X. J. Traditional Chinese medicine for COVID-19 treatment. Pharmacological Research vol. 155 (2020).

18. Stebbing, J. et al. COVID-19: combining antiviral and anti-inflammatory treatments. The Lancet Infectious Diseases vol. 20 400-402 (2020).

19. Gordon, C. J., Tchesnokov, E. P., Feng, J. Y., Porter, D. P. \& Götte, M. The antiviral compound remdesivir potently inhibits RNAdependent RNA polymerase from Middle East respiratory syndrome coronavirus. Journal of Biological Chemistry vol. 295 4773-4779 (2020).

20. Nguyen, T. M., Zhang, Y. \& Pandolfi, P. P. Virus against virus: a potential treatment for 2019-nCov (SARS-CoV- 
2) and other RNA viruses. Cell Research vol. 30 189-190 (2020).

21. ML, S., JM, Y., YP, S. \& GH, S. Inhibitors of RAS Might Be a Good Choice for the Therapy of COVID-19 Pneumonia. Zhonghua Jie He He Hu Xi Za Zhi 43, (2020).

22. Lim, J. et al. Case of the index patient who caused tertiary transmission of coronavirus disease 2019 in Korea: The application of lopinavir/ritonavir for the treatment of COVID-19 pneumonia monitored by quantitative RT-PCR. J. Korean Med. Sci. 35, (2020).

23. Kruse, R. L. Therapeutic strategies in an outbreak scenario to treat the novel coronavirus originating in Wuhan, China [version 2; peer review: 2 approved]. F1000Research vol. 9 (2020).

24. Wang, M. et al. Remdesivir and chloroquine effectively inhibit the recently emerged novel coronavirus (2019$\mathrm{nCoV}$ ) in vitro. Cell Research vol. 30 269-271 (2020).

25. Wang, Z., Chen, X., Lu, Y., Chen, F. \& Zhang, W. Clinical characteristics and therapeutic procedure for four cases with 2019 novel coronavirus pneumonia receiving combined Chinese and Western medicine treatment. Biosci. Trends 14, (2020).

26. Holshue, M. L. et al. First Case of 2019 Novel Coronavirus in the United States. N. Engl. J. Med. 382, 929-936 (2020).

27. H.L. Zhang \& Y.X. Zhu. One highly suspected case of novel coronavirus pneumonia treated by Integrated Traditional Chinese and Western medicine and nucleic acid analysis. Tianjin J. Tradit. Chinese Med.

28. Blanco, J. L. et al. COVID-19 in patients with HIV: clinical case series. The Lancet HIV vol. 7 e314-e316 (2020).

29. Lancet, I. T. \& Wang, Y. Remdesivir for COVID-19 : challenges of underpowered studies. Lancet 6736, 3102231023 (2020).

30. COVID-19 Studies from the World Health Organization Database - ClinicalTrials.gov. https://clinicaltrials.gov/ct2/who_table.

31. Saha, S., Sengupta, K., Chatterjee, P., Basu, S. \& Nasipuri, M. Analysis of protein targets in pathogen-host interaction in infectious diseases: a case study on Plasmodium falciparum and Homo sapiens interaction network. Brief. Funct. Genomics 17, 441-450 (2017).

32. Halder, A. K., Dutta, P., Kundu, M., Basu, S. \& Nasipuri, M. Review of computational methods for virus-host protein interaction prediction: a case study on novel Ebola-human interactions. Brief. Funct. Genomics 17, 381-391 (2018).

33. Bailey, N. T. J. The mathematical theory of infectious diseases and its applications. 2nd edition. Math. theory Infect. Dis. its Appl. 2nd Ed. (1975).

34. Lucy Chin, Jordan Cox, Safiya Esmail, Mark Franklin, D. Le. COVID-19: Finding the Right Fit Identifying Potential Treatments Using a Data-Driven Approach. Drugbank White Pap. (2020).

35. Fostamatinib - DrugBank. https://www.drugbank.ca/drugs/DB12010.

36. Drug Approval Package: TAVALISSE (fostamatinib disodium hexahydrate). https://www.accessdata.fda.gov/drugsatfda_docs/nda/2018/209299Orig1s000TOC.cfm.

37. Saha, S., Chatterjee, P., Basu, S. \& Nasipuri, M. Detection of spreader nodes and ranking of interacting edges in $\begin{array}{llll}\text { Human-SARS-CoV protein interaction network. bioRxiv 2020.04.12.038216 (2020) } & \end{array}$ doi:10.1101/2020.04.12.038216.

38. Saha, S. et al. Computational modeling of Human-nCoV protein-protein interaction network. (2020).

39. Wishart, D. S. et al. DrugBank: a knowledgebase for drugs, drug actions and drug targets. Nucleic Acids Res. 36, D901-D906 (2008).

40. DrugBank. https://www.drugbank.ca/.

41. Kumar, S. COVID-19: A drug repurposing and biomarker identification by using comprehensive gene-disease associations through protein-protein interaction network analysis. Preprints (2020) doi:10.20944/preprints202003.0440.v1.

42. Piñero, J. et al. DisGeNET: a discovery platform for the dynamical exploration of human diseases and their genes. 
Database (Oxford). 2015, bav028-bav028 (2015).

43. MULTIPLE LIST COMPARATOR - A free online tool to find list overlaps and draw Venn diagrams. http://molbiotools.com/listcompare.html.

44. Mattingly, C. J., Rosenstein, M. C., Colby, G. T., Forrest, J. N. \& Boyer, J. L. The Comparative Toxicogenomics Database (CTD): A resource for comparative toxicological studies. in Journal of Experimental Zoology Part A: Comparative Experimental Biology vol. 305 689-692 (2006).

45. FDA approves fostamatinib tablets for ITP | FDA. https://www.fda.gov/drugs/resources-information-approveddrugs/fda-approves-fostamatinib-tablets-itp.

46. McKeage, K. \& Lyseng-Williamson, K. A. Fostamatinib in chronic immune thrombocytopenia: a profile of its use in the USA. Drugs Ther. Perspect. 34, 451-456 (2018).

47. Fujita, K. I. Food-drug interactions via human cytochrome P450 3A (CYP3A). Drug Metabolism and Drug Interactions vol. 20 195-217 (2004).

48. Lippi, G., Plebani, M. \& Henry, B. M. Thrombocytopenia is associated with severe coronavirus disease 2019 (COVID-19) infections: A meta-analysis. Clin. Chim. Acta 506, 145-148 (2020).

49. Jin, Z. et al. Structure of Mpro from COVID-19 virus and discovery of its inhibitors. Nature 1-9 (2020) doi:10.1038/s41586-020-2223-y.

50. Agrawal, M., Zitnik, M. \& Leskovec, J. Large-Scale Analysis of Disease Pathways in the Human Interactome. bioRxiv 189787 (2017) doi:10.1101/189787.

51. BioSNAP: Network datasets: Human protein-protein interaction network. https://snap.stanford.edu/biodata/datasets/10000/10000-PP-Pathways.html.

52. Pfefferle, S. et al. The SARS-Coronavirus-host interactome: Identification of cyclophilins as target for panCoronavirus inhibitors. PLoS Pathog. 7, (2011).

53. Bateman, A. et al. UniProt: The universal protein knowledgebase. Nucleic Acids Res. 45, D158-D169 (2017).

54. Chan, J. F. W. et al. Genomic characterization of the 2019 novel human-pathogenic coronavirus isolated from a patient with atypical pneumonia after visiting Wuhan. Emerg. Microbes Infect. 9, 221-236 (2020).

55. China releases genetic data on new coronavirus, now deadly | CIDRAP. https://www.cidrap.umn.edu/newsperspective/2020/01/china-releases-genetic-data-new-coronavirus-now-deadly.

56. Samadi, N. \& Bouyer, A. Identifying influential spreaders based on edge ratio and neighborhood diversity measures in complex networks. Computing 101, 1147-1175 (2019).

57. Wang, S. \& Wu, F. Detecting overlapping protein complexes in PPI networks based on robustness. Proteome Sci. 11, 1-8 (2013).

58. Dutta, P., Basu, S. \& Kundu, M. Assessment of Semantic Similarity between Proteins Using Information Content and Topological Properties of the Gene Ontology Graph. IEEE/ACM Trans. Comput. Biol. Bioinforma. 15, 839-849 (2018).

59. Consortium, G. O. \& others. The Gene Ontology (GO) database and informatics resource. Nucleic Acids Res 32 , D258-D261 (2004).

60. Emergency Use Authorization | FDA. https://www.fda.gov/emergency-preparedness-and-response/mcm-legalregulatory-and-policy-framework/emergency-use-authorization.

61. Harrison, C. Coronavirus puts drug repurposing on the fast track. Nat. Biotechnol. (2020) doi:10.1038/d41587-02000003-1.

62. Cao, B. et al. A Trial of Lopinavir-Ritonavir in Adults Hospitalized with Severe Covid-19. N. Engl. J. Med. (2020) doi:10.1056/nejmoa2001282.

63. de Wit, E. et al. Prophylactic and therapeutic remdesivir (GS-5734) treatment in the rhesus macaque model of MERS-CoV infection. Proc. Natl. Acad. Sci. U. S. A. 117, 6771-6776 (2020).

64. Emergency Access to Remdesivir Outside of Clinical Trials. https://www.gilead.com/purpose/advancing-globalhealth/covid-19/emergency-access-to-remdesivir-outside-of-clinical-trials. 
65. Remdesivir Clinical Trials. https://www.gilead.com/purpose/advancing-global-health/covid-19/remdesivir-clinicaltrials.

66. China approves antiviral favilavir to treat coronavirus - UPI.com. https://www.upi.com/Health_News/2020/02/17/China-approves-antiviral-favilavir-to-treatcoronavirus/5291581953892/.

67. Taiwan synthesizes anti-viral drug favilavir for COVID-19 patients - Focus Taiwan. https://focustaiwan.tw/scitech/202003020012.

68. Lu, R. et al. Genomic characterisation and epidemiology of 2019 novel coronavirus: implications for virus origins and receptor binding. Lancet 395, 565-574 (2020).

69. Ciaglia, E., Vecchione, C. \& Puca, A. A. COVID-19 Infection and Circulating ACE2 Levels: Protective Role in Women and Children. Front. Pediatr. 8, 206 (2020).

70. Xiao, H., Xu, L. H., Yamada, Y. \& Liu, D. X. Coronavirus spike protein inhibits host cell translation by interaction with eIF3f. PLoS One 3, (2008).

71. Ma-Lauer, Y. et al. P53 down-regulates SARS coronavirus replication and is targeted by the SARS-unique domain and PLpro via E3 ubiquitin ligase RCHY1. Proc. Natl. Acad. Sci. U. S. A. 113, E5192-E5201 (2016).

72. Wendt, L. et al. The Ebola Virus Nucleoprotein Recruits the Nuclear RNA Export Factor NXF1 into Inclusion Bodies to Facilitate Viral Protein Expression. Cells 9, 187 (2020).

73. Luo, C. et al. Nucleocapsid protein of SARS coronavirus tightly binds to human cyclophilin A. Biochem. Biophys. Res. Commun. 321, 557-565 (2004).

74. Nigro, P., Pompilio, G. \& Capogrossi, M. C. Cyclophilin A: A key player for human disease. Cell Death and Disease vol. 4 e888 (2013).

75. Chai, Q. et al. HIV-1 counteracts an innate restriction by amyloid precursor protein resulting in neurodegeneration. Nat. Commun. 8, (2017).

76. Chen, Z. et al. GRB2 Interaction with the Ecotropic Murine Leukemia Virus Receptor, mCAT-1, Controls Virus Entry and Is Stimulated by Virus Binding. J. Virol. 86, 1421-1432 (2012).

77. Venkataraman, T. \& Frieman, M. B. The role of epidermal growth factor receptor (EGFR) signaling in SARS coronavirus-induced pulmonary fibrosis. Antiviral Research vol. 143 142-150 (2017).

78. Meng, X.-Y., Zhang, H.-X., Mezei, M. \& Cui, M. Molecular Docking: A powerful approach for structure-based drug discovery. Curr. Comput. Aided. Drug Des. 7, 146 (2011).

79. RCSB PDB - 6LU7: The crystal structure of COVID-19 main protease in complex with an inhibitor N3. https://www.rcsb.org/structure/6lu7.

80. Stella, V. J., Charman, W. N. A. \& Naringrekar, V. H. Prodrugs. Drugs 29, 455-473 (1985).

81. Baluom, M., Grossbard, E. B., Mant, T. \& Lau, D. T. W. Pharmacokinetics of fostamatinib, a spleen tyrosine kinase (SYK) inhibitor, in healthy human subjects following single and multiple oral dosing in three phase I studies. $B r . J$. Clin. Pharmacol. 76, 78-88 (2013).

82. RCSB PDB - 3FQS: Crystal structure of spleen tyrosine kinase complexed with R406. https://www.rcsb.org/structure/3fqs.

83. Villaseñor, A. G. et al. Structural Insights for Design of Potent Spleen Tyrosine Kinase Inhibitors from Crystallographic Analysis of Three Inhibitor Complexes. Chem. Biol. Drug Des. 73, 466-470 (2009).

84. RCSB PDB - 6K32: RdRp complex. https://www.rcsb.org/structure/6K32.

85. Li, X. et al. Structure of RdRps Within a Transcribing dsRNA Virus Provides Insights Into the Mechanisms of RNA Synthesis. J. Mol. Biol. 432, 358-366 (2020).

86. Tavakolian, S., Goudarzi, H. \& Faghihloo, E. Cyclin-dependent kinases and CDK inhibitors in virus-associated cancers. Infectious Agents and Cancer vol. 15 1-12 (2020).

87. ZFIN Gene: ntrk1. https://zfin.org/ZDB-GENE-980526-118. 
88. Kuhn, M., von Mering, C., Campillos, M., Jensen, L. J. \& Bork, P. STITCH: interaction networks of chemicals and proteins. Nucleic Acids Res. 36, D684-D688 (2008).

89. Szklarczyk, D. et al. STITCH 5: augmenting protein-chemical interaction networks with tissue and affinity data. Nucleic Acids Res. 44, D380-D384 (2016).

90. Griffith, M. et al. DGIdb: Mining the druggable genome. Nat. Methods 10, 1209-1210 (2013).

91. Gordon DE, Jang GM, Bouhaddou M, Xu J, Obernier K, White KM, et al. A SARS-CoV-2 protein interaction map reveals targets for drug repurposing. Nature 2020;583:459-68. https://doi.org/10.1038/s41586-020-2286-9.

\section{Acknowledgements}

This work is partially supported by the CMATER research laboratory of the Computer Science and Engineering Department, Jadavpur University, India, PURSE-II and UPE-II grants. Subhadip Basu acknowledges Department of Biotechnology grant (BT/PR16356/BID/7/596/2016), Government of India. For research fellowship support, Anup Kumar Halder acknowledges the Visvesvaraya PhD Scheme for Electronics \& IT, an initiative of Ministry of Electronics \& Information Technology (MeitY), Government of India. We acknowledge Prof. Jacek Sroka (Institute of Informatics, University of Warsaw) for his contribution toward the developments of the fuzzy ppi methods.

\section{Author contributions statement}

S.S., A.K.H. and S.B. conceived the idea of the research and wrote the manuscript. S.S. and A.K.H. conducted the experiment(s).P.C, S.S.B., M.N., D.B and S.B. analyzed the results. M.N., P.C and S.B. reviewed the manuscript.

\section{Additional information}

Competing interests: The authors declare no competing interests.

All queries should be sent to the corresponding author's email: subhadip.basu@jadavpuruniversity.in 